\title{
Climate impact on the development of Pre-Classic Maya civilisation
}

\author{
Kees Nooren $^{1}$, Wim Z. Hoek ${ }^{1}$, Brian J. Dermody ${ }^{1,2}$, Didier Galop ${ }^{3}$, Sarah Metcalfe ${ }^{4}$, Gerald Islebe ${ }^{5}$, and \\ Hans Middelkoop ${ }^{1}$ \\ ${ }^{1}$ Faculty of Geosciences, Utrecht University, 3508 TC Utrecht, the Netherlands \\ ${ }^{2}$ Copernicus Institute of Sustainable Development, Utrecht University, 3508 TC Utrecht, the Netherlands \\ ${ }^{3}$ Université Jean Jaurès, CNRS, UMR 5602 GEODE, 31058 Toulouse, France \\ ${ }^{4}$ School of Geography, University of Nottingham, Nottingham NG7 2RD, UK \\ ${ }^{5}$ El Colegio de la Frontera Sur, Unidad Chetumal Herbario, Chetumal, AP 424 Quintana Roo, Mexico
}

Correspondence: Kees Nooren (k.nooren@gmail.com)

Received: 23 February 2018 - Discussion started: 6 March 2018

Revised: 20 June 2018 - Accepted: 25 July 2018 - Published: 20 August 2018

\begin{abstract}
The impact of climate change on the development and disintegration of Maya civilisation has long been debated. The lack of agreement among existing palaeoclimatic records from the region has prevented a detailed understanding of regional-scale climatic variability, its climatic forcing mechanisms and its impact on the ancient Maya. We present two new palaeo-precipitation records for the central Maya lowlands, spanning the Pre-Classic period (1800 BCE$250 \mathrm{CE}$ ), a key epoch in the development of Maya civilisation. A beach ridge elevation record from world's largest late Holocene beach ridge plain provides a regional picture, while Lake Tuspan's diatom record is indicative of precipitation changes at a local scale. We identify centennial-scale variability in palaeo-precipitation that significantly correlates with the North Atlantic $\delta^{14} \mathrm{C}$ atmospheric record, with a comparable periodicity of approximately 500 years, indicating an important role of North Atlantic atmospheric-oceanic forcing on precipitation in the central Maya lowlands. Our results show that the Early Pre-Classic period was characterised by relatively dry conditions, shifting to wetter conditions during the Middle Pre-Classic period, around the well-known $850 \mathrm{BCE}(2.8 \mathrm{ka})$ event. We propose that this wet period may have been unfavourable for agricultural intensification in the central Maya lowlands, explaining the relatively delayed development of Maya civilisation in this area. A return to relatively drier conditions during the Late Pre-Classic period coincides with rapid agricultural intensification in the region and the establishment of major cities.
\end{abstract}

\section{Introduction}

During the last decades, a wealth of new data has been gathered to understand human-environmental interaction and the role of climate change in the development and disintegration of societies in the Maya lowlands (e.g. Akers et al., 2016; Douglas et al., 2015, 2016; Dunning et al., 2012, 2015; Lentz et al., 2014; Turner and Sabloff, 2012). Previous studies have emphasised the impact of prolonged droughts and their possible link with social downturn, such as the PreClassic Abandonment and the Classic Maya Collapse (Ebert et al., 2017; Hoggarth et al., 2016; Lentz et al., 2014; Kennett et al., 2012; Medina-Elizalde et al., 2010, 2016; Haug et al., 2003; Hodell et al., 1995, 2001, 2005). Less attention has been given to episodes of excessive rain and floods that may also have severely impacted ancient Maya societies (e.g. Iannone, 2014). Evidence for such impacts is found in the fact that floods, as well as droughts, are an important theme depicted in the remaining ancient Maya codices (Fig. 1) (Thompson, 1972) and Maya mythological stories (Valásquez Garciá, 2006).

One of the main challenges in palaeoclimatic reconstructions is to unravel climate from human-induced changes. Maya societies played a key role in the formation of the landscape, but the degree of human-induced impact remains highly debated (Hansen, 2017; Beach et al., 2015; Ford and Nigh, 2015). For example, it is proposed that the increase in sedimentation rate after $1000 \mathrm{BCE}$ at Lake Salpeten (Anselmetti et al., 2007) and Petén-Itzá (Mueller et al., 2009) is 


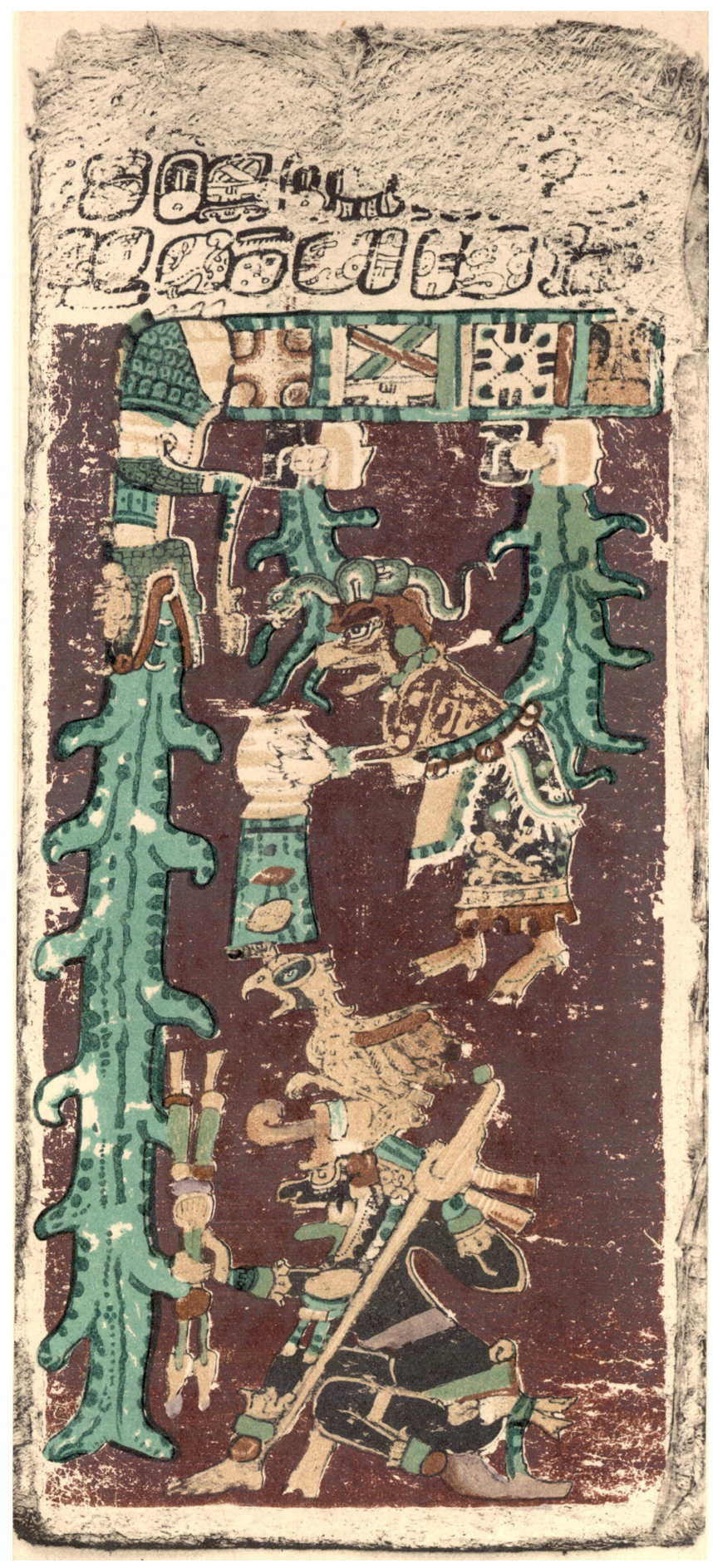

Figure 1. The image on p. 74 of the Dresden Codex depicts a torrential downpour probably associated with a destructive flood (Thompson, 1972).

related to human-induced soil erosion. However, other highresolution lake records from the area do not show a significant increase in sedimentation rate during the Pre-Classic or Classic period (e.g. Wahl et al., 2014), and past volcanic activity could have been responsible for the deposition of smectite-rich clay layers in inland lakes (Tankersley et al., 2016; Nooren et al., 2017a). Palynological records from the central Maya lowlands (CML; Fig. 2) show no evidence of widespread land clearance and agriculture before $\sim 400 \mathrm{BCE}$ (Wahl et al., 2007; Islebe et al., 1996; Leyden, 1987), and there is growing consensus that the decline in the percentage of lowland tropical forest pollen during the Pre-Classic period (Galop et al., 2004; Islebe et al., 1996; Leyden, 1987) was caused by climatic drying instead of deforestation (Torrescano and Islebe, 2015; Wahl et al., 2014; Mueller et al., 2009).

In this paper, we present two new palaeo-precipitation records reflecting precipitation changes in the CML. The records span the Pre-Classic period (1800 BCE-250 CE), when Maya societies in the CML transformed from predominantly mobile hunter-gatherers in the Early Pre-Classic period (e.g. Inomata et al., 2015; Coe, 2011; Lohse, 2010) to complex sedentary societies that founded impressive cities like El Mirador by the later part of the Pre-Classic period (Hansen, 2017; Inomata and Henderson, 2016). The period of rapid growth in these centralised societies probably occurred much later than previously thought, sometime after the start of the Late Pre-Classic period around 400 BCE (Inomata and Henderson, 2016). This raises the question for the reason behind the delayed development of societies in this area, which was to become the core area of Maya civilisation during the following Classic period (250-900 CE). There is recent evidence that climate during the Middle Pre-Classic Period (1000-400 BCE) may have been less stable than recently reported (Ebert et al., 2017). We propose that anomalously wet conditions could have been unfavourable for the intensification of maize-based agriculture, which formed the underlying subsistence economy responsible for the development of many neighbouring Meso-American societies during this period.

The CML have been intensively studied, and several welldated speleothem, palynological and limnological records have been obtained for this area (Díaz et al., 2017; Akers et al., 2016; Douglas et al., 2015; Wahl et al., 2014; Kennett et al., 2012; Mueller et al., 2009; Metcalfe et al., 2009; Domínguez-Vázquez and Islebe, 2008; Galop et al., 2004; Rosenmeier et al., 2002; Islebe et al., 1996) (Figs. 2 and A1). However, palaeo-precipitation signals from these records and those from adjacent areas in the Yucatán and central Mexico exhibit large differences among records (Fig. A2), making the reconstruction and interpretation of larger-scale precipitation for the region a challenge (Lachniet et al., 2013, 2017; Douglas et al., 2016; Metcalfe et al., 2015). Existing climate reconstructions mostly represent local changes and are predominantly based on oxygen isotope variability, although some new proxies have been introduced recently (e.g. Díaz et al., 2017; Douglas et al., 2015).

We present a regional-scale palaeo-precipitation record for the CML, extracted from world's largest late Holocene beach 
(c)
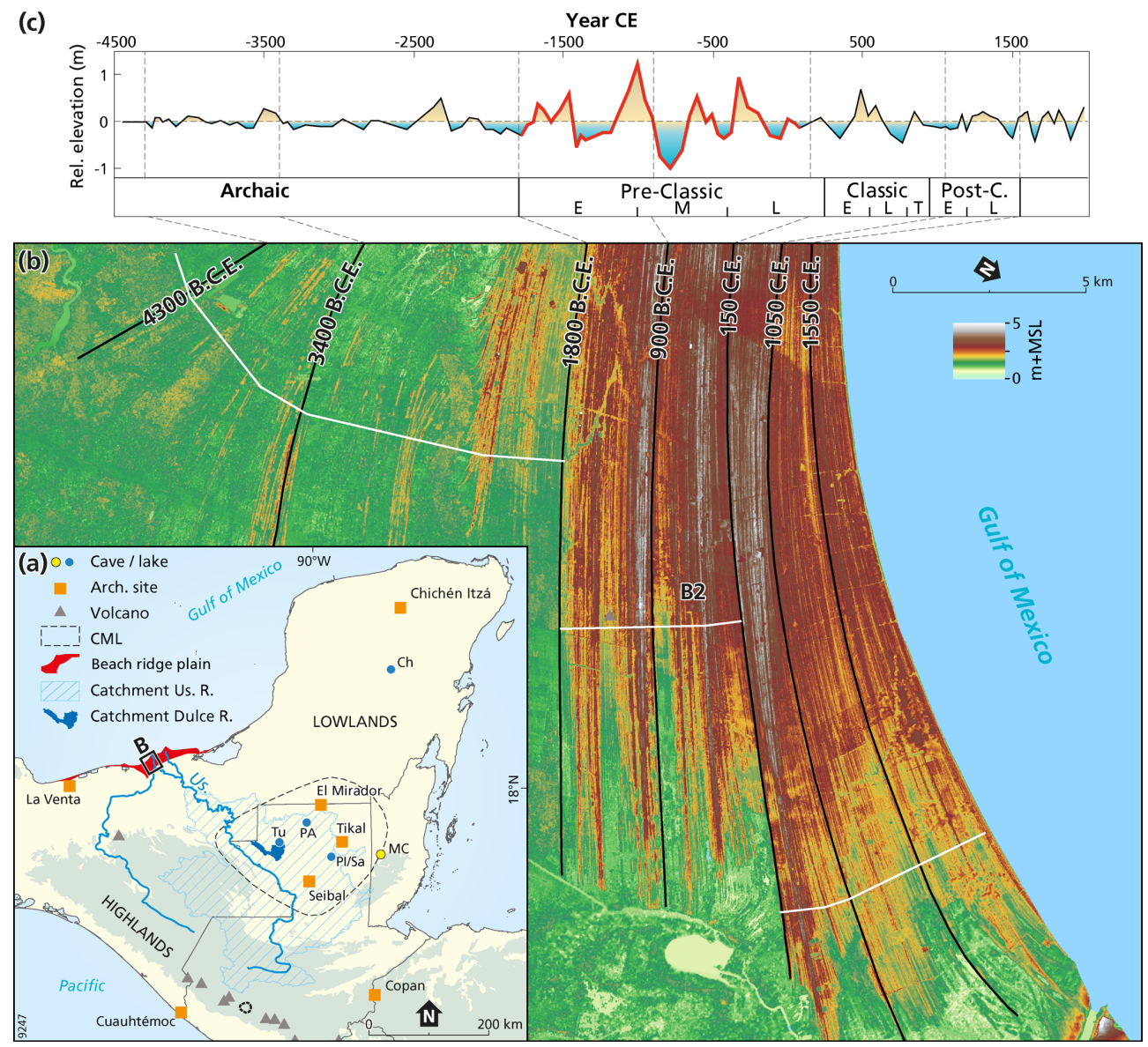

Figure 2. A large part of the central Maya lowlands (outlined with a black dashed line) is drained by the Usumacinta (Us.) River (a). During the Pre-Classic period this river was the main supplier of sand contributing to the formation of the extensive beach ridge plain at the Gulf of Mexico coast (b). Periods of low rainfall result in low river discharges and are associated with relatively elevated beach ridges. The extent of the watersheds of the Usumacinta and Dulce River is calculated from the Shuttle Radar Topography Mission (SRTM) 1-arc data (USGS, 2009). Indicated are archaeological sites (squares) and proxy records discussed in the text: Tu: Lake Tuspan; Ch: Lake Chichancanab; PI: Lake Petén-Itzá; MC: Macal Chasm cave; PA: Lago Puerto Arturo.

ridge sequence at the Gulf of Mexico coast (Fig. 2b). The beach ridge record captures changes in river discharge resulting from precipitation patterns over the entire catchment of the Usumacinta River and thus represents regional changes in precipitation over the CML (Nooren et al., 2017b). Currently the annual discharge of the Usumacinta river is approximately $2000 \mathrm{~m}^{3} \mathrm{~s}^{-1}$, corresponding to $\sim 40 \%$ of the excess or effective rain falling in the $70700 \mathrm{~km}^{2}$ large catchment (Nooren et al., 2017b). Mean annual precipitation within the catchment is $\sim 2150 \mathrm{~mm}$, with $80 \%$ falling during the boreal summer, related to the North American or Meso-American monsoon system (Lachniet et al., 2013, 2017; Metcalfe et al., 2015). The interpretation of the beach ridge record is supported by a new multi-proxy record from Lake Tuspan, an oligosaline lake situated within the CML. The lake receives most of its water from a relatively small catchment of $770 \mathrm{~km}^{2}$ (Fig. 2) and hence provides a local precipitation record, to complement the regional signal from the beach ridge sequence.

\subsection{Regional palaeo-precipitation signal}

The coastal beach ridges consist of sandy material originating from the Grijalva and Usumacinta rivers, topped by windblown beach sand (Nooren et al., 2017b). Although multiple factors determine the final elevation of the beach ridges, it has been shown that during the period $1775 \pm 95 \mathrm{BCE}$ to $30 \pm 95 \mathrm{CE}$ (at $1 \sigma$ ), roughly coinciding with the Pre-Classic period, beach ridge elevation was primarily determined by the discharge of the Usumacinta river. Low-elevation anomalies of the beach ridges occur in periods with increased river sediment discharge, which in turn is the product of high precipitation within the river catchment. Under these conditions, beach ridges develop relatively rapidly and are exposed to wind for a shorter period. In contrast, during peri- 
ods of drought, sediment supply to the coast is reduced, resulting in a decreased seaward progradation rate of the beach ridge plain. This leaves a longer period for aeolian accretion on the beach ridges near the former shoreline, resulting in higher beach ridges (Nooren et al., 2017b). Hence, variations in beach ridge elevation reflect changes in rainfall over the Usumacinta catchment and thereby represent catchment-aggregated precipitation, rather than a local signal. The very high progradation rates and the very robust age-distance model (Fig. A3), with uncertainties of the calibrated ages not exceeding 60-70 years (at $1 \sigma$ ), effectively allow the reconstruction of palaeo-precipitation at centennial timescales.

\subsection{Local palaeo-precipitation signal: Lake Tuspan record}

During dry periods, a reduced riverine input of freshwater and a lowering of the lake level enhance the effect of evaporation and increase the salinity of the lake water. Diatom communities within oligo- to hypersaline lakes are strongly influenced by lake water salinity (Reed, 1998; Gasse et al., 1995), and we therefore determined diatom assemblage changes within the Lake Tuspan sediment record (Fig. 3) to reconstruct palaeosalinities of the lake water, reflecting palaeoprecipitation in the lake's catchment via changes in the balance of precipitation and evaporation.

\section{Methods}

\subsection{Beach ridge sequence}

Beach ridges elevations were extracted from a digital elevation model (DEM) of the coastal plain along the transects indicated in Fig. 2 (Nooren et al., 2017b). The DEM is based on lidar data originally acquired in April-May 2008 and processed by Mexico's National Institute of Statistics and Geography (INEGI), Mexico. The relative beach ridge elevation is defined as the difference between the beach ridge elevation and the long-term ( $\sim 500$ years) running mean (Fig. A3). The age distance model is based on 35 accelerator mass spectrometry (AMS) ${ }^{14} \mathrm{C}$ dated terrestrial macro-remains (mainly leaf fragments isolated from organic debris layers) and $20 \mathrm{op}-$ tically stimulated luminescence (OSL) dated sand samples (determined on small aliquots of quartz grains) (Nooren et al., 2017b).

\subsection{Lake Tuspan}

Two parallel cores, Tuspan cores B and C, were taken with a Russian corer (type GYK) in shallow water near the inflow of the Dulce River (not to be confused with the Dulce River that drains lake Izabal in eastern Guatemala), not far from core A, which has been studied for pollen (Galop et al., 2004). Semi-quantitative analyses of $\mathrm{Si}, \mathrm{S}, \mathrm{K}, \mathrm{Ca}, \mathrm{Ti}, \mathrm{Mn}$ and
Fe were conducted on both cores with an X-ray fluorescence core scanner (type AVAATECH) at $0.5 \mathrm{~cm}$ intervals. Deposits of large floods were identified on the basis of elevated concentrations of $\mathrm{Si}, \mathrm{Fe}, \mathrm{Ti}$ and $\mathrm{Al}$ (Davies et al., 2015), with peak concentrations exceeding a 1 standard deviation threshold above the mean.

Core $\mathrm{C}$ was investigated for amorphous silica, charred plant fragments and diatoms (Figs. 3, A4 and A5). The core was subsampled at $4-12 \mathrm{~cm}$ contiguous intervals, each interval representing 25-80 years. In addition, $371 \mathrm{~cm}$ samples (representing $\sim 6.5$ years) were processed using the method outlined by Battarbee (1973) to determine diatom concentrations and short-term variability (decadal scale). Subsamples were treated with $\mathrm{HCl}(10 \%)$ to remove calcium carbonate. Large organic particles were removed by wet sieving $(250 \mu \mathrm{m}$ mesh), and charred plant fragments $>250 \mu \mathrm{m}$ were counted under a dissection microscope. Remaining organic material was removed by heavy liquid separation using a sodium polywolframate solution with a density of $2.0 \mathrm{~g} \mathrm{~cm}^{-3}$. A silicious residue, denoted "amorphous silica" was subsequently removed by heavy liquid separation using a sodium polywolframate solution with a density of $2.3 \mathrm{~g} \mathrm{~cm}^{-3}$, and dry weight was determined after drying of the samples at $105^{\circ} \mathrm{C}$.

Slides were prepared from the remaining material. Diatoms were identified, counted and reported as percentages of the total diatom sum, excluding the small and often dominant Denticula elegans and Nitzschia amphibia species. These species show a large variability on short timescales (Fig. A5) and are not indicative of changes at centennial timescale. We relate changes in diatom assemblages mainly to lake water salinity changes. The first principal component on the entire assemblage (PC-1) is interpreted as a palaeosalinity indicator. Diatom taxonomy is mainly after Patrick and Reimer $(1966,1975)$ and Novelo et al. (2007). We identified Plagiotropis arizonica following Czarnecki and Blinn (1978), Mastogloia calcarea following Lee et al. (2014), and Cyclotella petenensis following Paillès et al. (2018).

The age-depth model for core $\mathrm{C}$ is based on seven AMS radiocarbon-dated terrestrial samples and stratigraphical correlation with core A (Fleury et al., 2014). We used a linear regression between the available radiocarbon-dated samples (Fig. A7), which is comparable with the age-depth model of Fleury et al. (2014) for the time window between $\sim 2500 \mathrm{BCE}$ and $1000 \mathrm{CE}$.

\subsection{Wavelet transfer functions}

The relation between our beach ridge and diatom record and other palaeo-precipitation records from the Maya lowlands and nearby regions (Figs. A1 and A2) were investigated by wavelet transform coherence (WTC) analyses using the software developed by Grinsted et al. (2004). We also applied WTC to compare our record with North Atlantic ice drift 


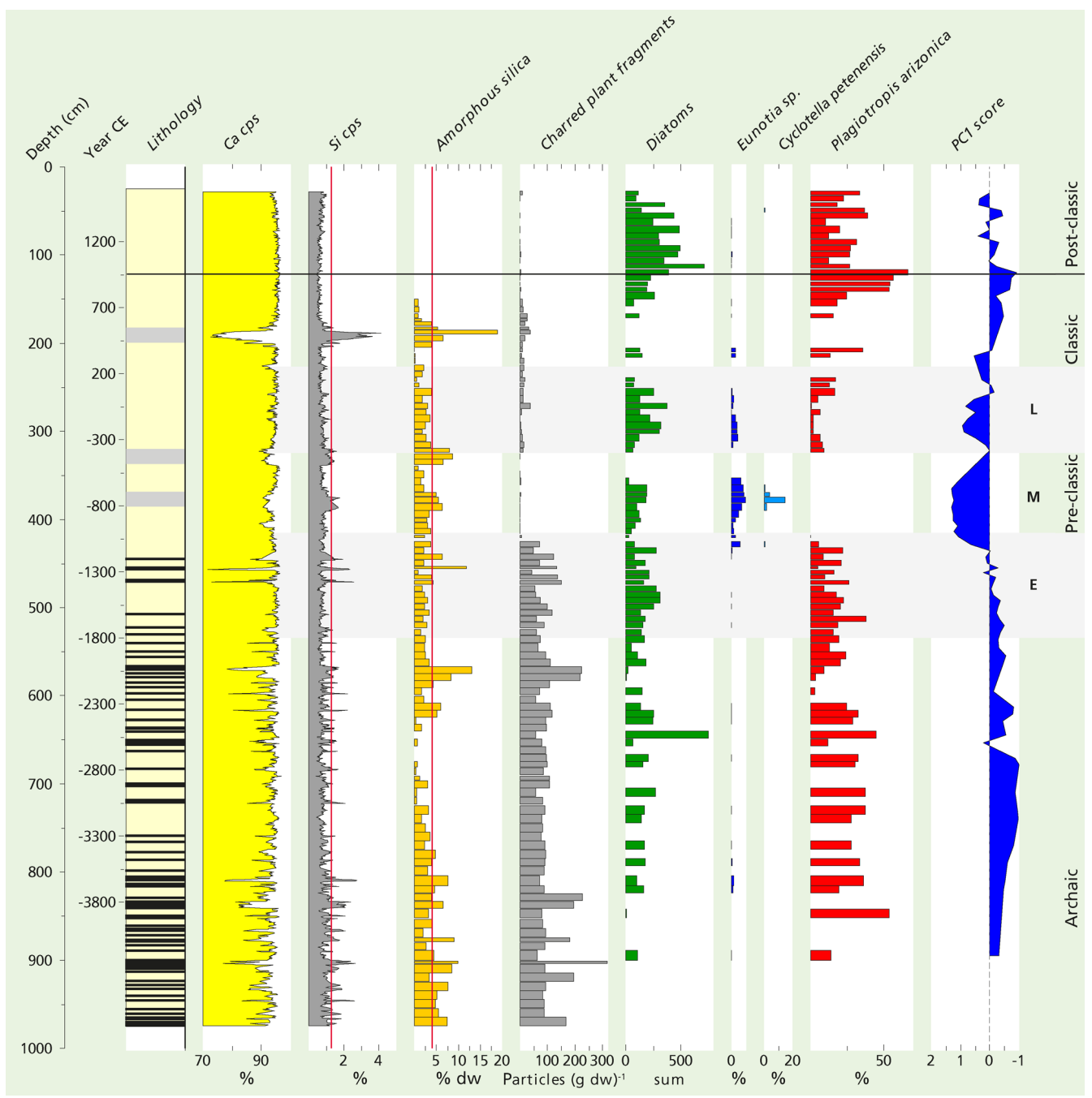

Figure 3. Summarised proxy record of Lake Tuspan sediment core C. In the lithological column black lines represent large flood layers and grey boxes turbidites. $\mathrm{Ca}$ and $\mathrm{Si}$ (in cps: counts per second) are presented here as a percentage of total counts. Vertical lines (red) in the (amorphous) Si graphs indicate the 1 standard deviation threshold above the mean. For the diatom record only the relative abundance of "key" diatom species are shown here. Denticula elegans and Nitzschia amphibia were excluded from the diatom sum. Notice the abrupt change around $1100 \mathrm{BCE}$.

record (Bond et al., 2001) and the Northern Hemisphere atmospheric $\delta^{14} \mathrm{C}$ record (Reimer et al., 2013) to gain an understanding of the forcing of the regional changes in precipitation we observe. The record of drift ice from the North Atlantic is bimodally distributed, oscillating between periods of low and high concentrations of hematite-stained grains. The time series was therefore transformed into a record of percentiles based on its cumulative distribution function to avoid leakage of the square wave into frequency bands outside the fundamental period (Grinsted et al., 2004). CWT applies Monte Carlo methods to test for significance. In this case we set the alpha value at $5 \%$. Time periods and periodicities enclosed within the black lines of in our wavelet analysis indicate common power between time series with $95 \%$ confidence.

\section{Results}

\subsection{Beach ridge record}

As described above, when beach ridge elevation is largely driven by the discharge of the Usumacinta River, periods of relative high (low) beach ridges correspond to relatively drier (wetter) conditions in the Usumacinta catchment (Fig. 2). The beach ridge record shows clear centennial-scale variability, with an exceptionally dry phase centred around $1000 \pm$ $95 \mathrm{BCE}$ and a subsequent pronounced wet phase centred around $800 \pm 95 \mathrm{BCE}$. 


\subsection{Diatom record Lake Tuspan}

The sediment stratigraphy of core $\mathrm{C}$ can be divided into two main units. Below $4.3 \mathrm{~m}$ the core is clearly laminated, and $0.5-4 \mathrm{~cm}$ thick dark palaeo-flood layers contrast with the predominantly light-coloured calcareous deposits. The flood layers are characterised by elevated detrital input, resulting in elevated concentrations of $\mathrm{Si}$, amorphous silica, and charred plant fragments. The average recurrence time of large floods was approximately 50 years. Sediments from 0.25 to $4.3 \mathrm{~m}$ depth are vaguely laminated, with three distinct decimetrethick turbidite layers (Fig. 3).

The interpretation of PC-1 (Fig. 3) as an indicator of lake salinity and hence relative dryness (see the "Methods" section) is supported by the fact that low or negative PC-1 values are driven by relatively high percentages of Plagiotropis arizonica (Fig. 3), a diatom species characteristic of high-conductivity water bodies (Czarnecki and Blinn, 1978) as well as other benthic, high-salinity/alkalinity species such as Anomoeoneis sphaerophora and Craticula cuspidata (Fig. A4).

A drastic change from dry to wet conditions occurred around $4.3 \mathrm{~m}$ depth $(\sim 1100 \mathrm{BCE})$, with the loss of salinity tolerant taxa and higher proportions of freshwater taxa such as Eunotia sp. and Cyclotella petenensis (Fig. 3). This coincides with the observed lithological shift from clearly to vaguely laminated sediments. After relatively high/positive PC-1 values during the Middle and Late Pre-Classic Period we observe a decreasing trend in PC-1 values during the following Classic Period, indicating a gradual increase in lake water salinity. Low PC-1 values between 800 and $950 \mathrm{CE}$ are in accordance with many palaeo-records from the area (Fig. A2) indicating periods of prolonged droughts during the Late Classic Period.

\subsection{Wavelet transfer function}

WTC analysis (Grinsted et al., 2004) indicates in-phase coherence between the beach ridge record and the recently extended and revised calcite $\delta^{18} \mathrm{O}$ speleothem record from Macal Chasm cave (Akers et al., 2016) (Fig. A7). The inphase relationship between the two records is significant above a $5 \%$ confidence level at centennial timescales during the Pre-Classic Period. We did not find significant relationships between the beach ridge record and other palaeoprecipitation records from the CML nor with records from the Yucatán and central Mexico (Fig. A2), except for a significant in-phase coherence at a centennial timescale with the Pyrgophorus sp. $\delta^{18} \mathrm{O}$ record from Lake Chichancanab (Hodell et al., 1995).

\section{Discussion}

\subsection{Climate change in the CML during the Pre-Classic period}

\subsubsection{Early Pre-Classic period (1800-1000 BCE)}

Both beach ridge and diatom records indicate that the onset of the Early Pre-Classic period was relatively dry (Fig. 4). Despite the predominantly dry conditions, large floods still occurred, as demonstrated by the repetitive input of fluvial material into Lake Tuspan. Periods with the highest fluvial sediment input coincided with periods of increased input of charcoal into Lake Petén-Itzá (Schüpbach et al., 2015) (Fig. A2). Because the CML were still sparsely populated during the Early Pre-Classic period (Inomata et al., 2015) we relate the presence of charcoal to the occurrence of wildfires.

After a transition to wetter conditions between 1500 and 1400 BCE, we observe a drying trend that culminated in a prolonged dry period at the end of the Early Pre-Classic period centred around $1000 \pm 95 \mathrm{BCE}$. Although this exceptionally dry phase is less apparent from Lake Tuspan's diatom record (Fig. 3), it has been recorded at many other sites within the CML. At Lake Puerto Arturo, high $\delta^{18} \mathrm{O}$ values in the gastropod Pyrgophorus sp. indicate that this was the driest period since $6300 \mathrm{BCE}$ (Wahl et al., 2014), and the recently extended and improved speleothem $\delta^{18} \mathrm{O}$ record from Macal Chasm indicates that this dry period was probably at least as severe as any prolonged droughts during the Classic and Post-Classic period (Akers et al., 2016). Dry conditions are reflected in high $\mathrm{Ca} / \Sigma(\mathrm{Ti}, \mathrm{Fe}, \mathrm{Al})$ values at Lake Petén-Itzá (Mueller et al., 2009), indicating elevated authigenic carbonate $\left(\mathrm{CaCO}_{3}\right)$ precipitation relative to the input of fluvial detrital elements ( $\mathrm{Ti}, \mathrm{Fe}$ and $\mathrm{Al}$ ) during this period; water level at this large lake must have dropped by at least $7 \mathrm{~m}$ (Mueller et al., 2009).

\subsubsection{Middle Pre-Classic period (1000-400 BCE)}

Both the beach ridge and the Lake Tuspan diatom records indicate a change to wetter conditions around 1000-850 BCE, causing major changes in hydrological conditions in the CML (Fig. 4). The diatom assemblages in the Lake Tuspan record show a major change in composition. Species indicative of meso- to poly-saline water almost completely disappear and are replaced by species indicating freshwater conditions (Fig. 4). In the lake sediments, this transition is also marked by a lithological shift from clearly to vaguely laminated sediments that lack repetitive large flood layers, while charred plant fragments are almost absent until 400 BCE. Similar abrupt lithological transitions were reported from Lake Chichancanab (Hodell et al., 1995) and Lake PeténItzá (Mueller et al., 2009), and Wahl et al. (2014) describe a regime shift at Puerto Arturo. The sudden reduction in charred plant fragments around $\sim 1000 \mathrm{BCE}$ at Lake Tuspan coincides with reduced concentrations of charcoal at Lake 

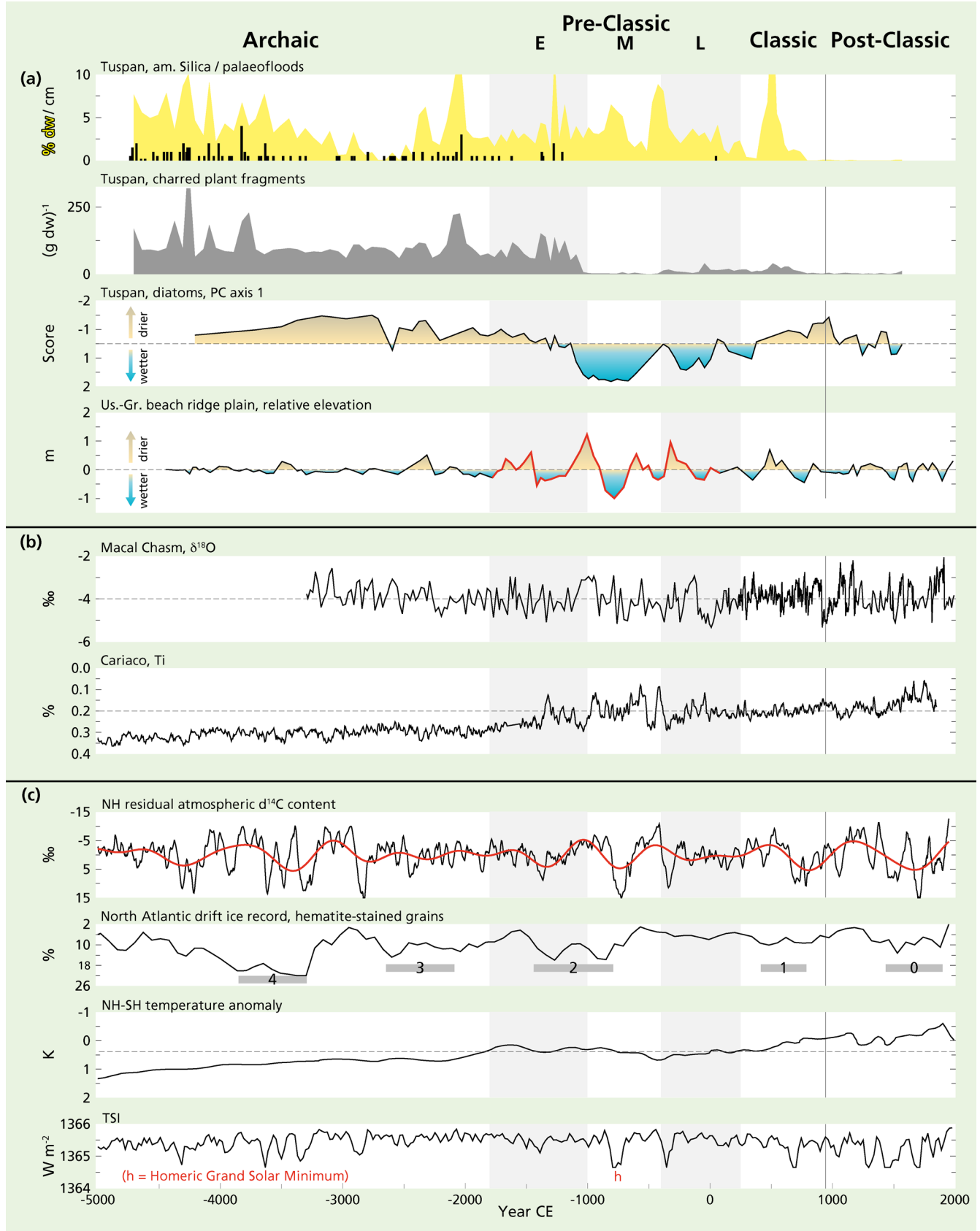

Figure 4. Comparison of the Lake Tuspan and beach ridge record (a) with local and proximal records from Macal Chasm cave (Akers et al., 2016) and the Cariaco basin (Haug et al., 2001) (b). We used an updated age-depth model for the Cariaco record (Fig. A9). Climate records related to North Atlantic atmospheric-oceanic forcing are indicated in panel (c), including the drift ice reconstruction from the North Atlantic (Bond et al., 2001), the Northern Hemisphere residual atmospheric $\delta^{14} \mathrm{C}$ content (Reimer et al., 2013), the Northern to Southern Hemisphere temperature anomaly (Schneider et al., 2014) and reconstructed total solar irradiance (TSI) (Steinhilber et al., 2012).

Petén-Itzá (Fig. A2) (Schüpbach et al., 2015) and Laguna Tortuguero, Puerto Rico (Burney and Pigott Burney, 1994), indicating rapid climatic changes over a large spatial scale.

\subsubsection{Late Pre-Classic period (400 BCE-250 CE)}

Both beach ridge and diatom record (Fig. 4) indicate that a relatively dry period occurred by the onset of the Late PreClassic period, which has not been identified in other proxy records from the region (Fig. A2), although high Pinus pollen percentages in the pollen record from Petapilla pond near Co- 
pan (McNeil et al., 2010) during this period may indicate dry conditions, as high Pinus pollen percentage at highland sites could be indicative of drier conditions (Domínguez-Vázquez and Islebe, 2008). The diatom record at Lake Tuspan (Fig. 3) shows a general increase in lake water salinity, indicating a gradual shift to drier conditions in the Late Pre-Classic period.

\subsection{Precipitation variability}

\subsubsection{Precipitation variability over long timescales}

The observed general drying trend over the last few thousand years is probably related to the southward shift of the Intertropical Convergence Zone (ITCZ) during the late Holocene. The shift occurred in response to orbitally forced changes in insolation (Haug et al., 2001), causing a gradual Northern Hemisphere cooling versus Southern Hemisphere warming (Fig. 4), thereby shifting the ITCZ towards the warming Southern Hemisphere (Schneider et al., 2014). Wetter conditions during the Middle Pre-Classic period may reflect a more northerly position of the ITCZ, which may be related to stronger easterly trade winds and the less frequent occurrence of winter season cold fronts, as beach ridge morphological changes suggest (Nooren et al., 2017b).

\subsubsection{Centennial-scale precipitation variability}

The coherence between the beach ridge record and the relatively well-dated Macal Chasm speleothem record gives us confidence that these records reflect regionally coherent variability at centennial timescales during the Pre-Classic period. Interestingly, the beach ridge record is significantly in antiphase with the North Atlantic ice drift record (Bond et al., 2001) and the Northern Hemisphere atmospheric $\delta^{14} \mathrm{C}$ record during the Pre-Classic Period (Reimer et al., 2013) (Fig. 5), suggesting an important role of North Atlantic atmosphericoceanic forcing on precipitation in the CML. The Northern Hemisphere atmospheric $\delta^{14} \mathrm{C}$ record shows a 512-year periodicity (Stuiver and Braziunas, 1993), which is similar to the observed $\sim 500$-year periodicity of the beach ridge record during the Pre-Classic period. Such a centennial-scale periodicity is not apparent in Lake Tuspan's diatom record (Fig. 3) nor in any of the other palaeo-precipitation records from the Maya lowlands (Fig. A2) but has been identified in the Ti record from Lake Juanacatlán in the highlands of central Mexico (Jones et al., 2015). This periodicity has been related to the intensity of the North Atlantic thermohaline circulation and variations in solar activity (Stuiver and Braziunas, 1993).

The coherence with fluctuations in solar irradiance is most evident during the $850 \mathrm{BCE}(2.8 \mathrm{ka})$ event, related to the Homeric Grand Solar Minimum. At that time, a strong decrease in the total solar irradiance resulted in higher atmospheric ${ }^{14} \mathrm{C}$ production and a change to cooler and wetter conditions in the Northern Hemisphere (e.g. Van Geel et al.,
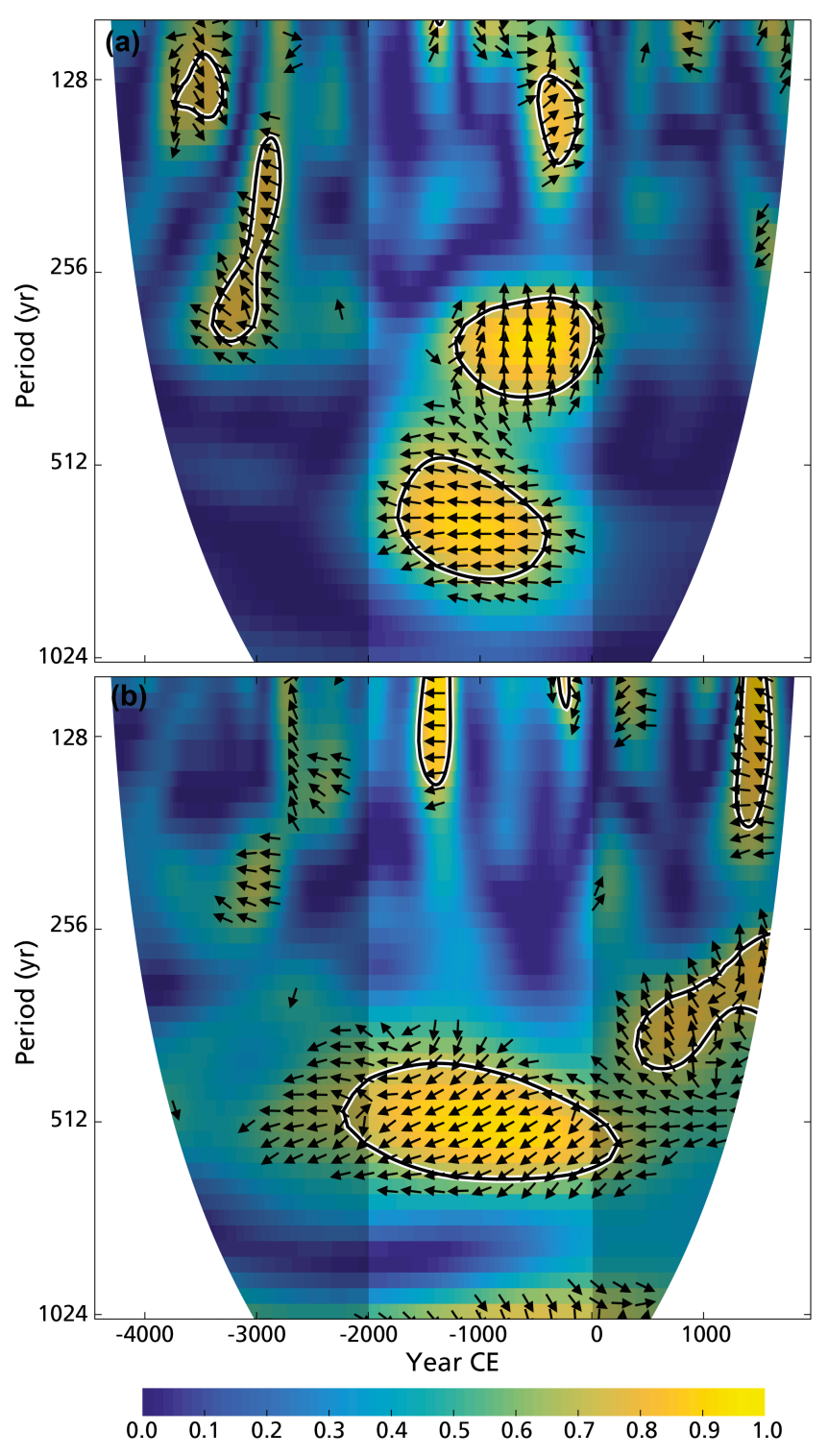

Figure 5. Wavelet transform coherence (WTC) analysis between the beach ridge record and the Northern Hemisphere atmospheric $\delta^{14} \mathrm{C}$ record (Reimer et al., 2013) (a) and the North Atlantic ice drift record (Bond et al., 2001) (b). The beach ridge record is significantly in anti-phase, with both records at an approximately 500-year timescale, indicating an important role of North Atlantic atmospheric-oceanic forcing on precipitation in the Maya lowlands during the Pre-Classic period. The $5 \%$ significance level against red noise is shown as a thick contour. Arrows indicate phase difference, with an in-phase relationship between records if arrows point to the right.

1996) and apparently also a shift to wetter conditions in the CML, evident from our two new palaeo-precipitation records (Fig. 4). This correlation should not be used as an analogue for modern precipitation variability, when periods of lower solar activity are associated with lower Usumacinta River discharge and hence less precipitation in the CML (Fig. A8). 
Probably due to a more northerly mean position of the ITCZ during the Pre-Classic Period, precipitation responded differently to solar forcing than today.

It has previously been suggested that there was a coherent response to the late Holocene southward shift of the ITCZ in both northern South America and the Maya lowlands (Haug et al., 2003), implying that the beach ridge record should be in-phase with the Cariaco Ti record (Haug et al., 2001). Although the Cariaco record indicates large centennial-scale variability in precipitation over northern South America (Fig. 4), this variability is not significantly correlated with the beach ridge record. The correlation improved slightly using an updated age-depth model for Cariaco (Fig. A9) but remains insignificant, probably as a consequence of uncertainties in the chronological control of both records or because of a more prominent influence of the North Atlantic climatic forcing mechanisms in the Maya lowlands.

\subsection{Precipitation versus human development in the $\mathrm{CML}$}

Our records indicate that the Early Pre-Classic period in the CML was relatively dry. During that period, the CML were still sparsely populated by moving hunter-gatherers. It is highly likely that before maize became sufficiently productive to sustain sedentism, the karstic lowlands were less attractive for humans than the coastal wetlands along the Gulf of Mexico and Pacific coast, where natural resources were abundantly present to successfully sustain a huntinggathering subsistence system (Inomata et al., 2015). Reliance on cultivated crops, most notably maize, rapidly increased after the onset of the Middle Pre-Classic period around $1000 \mathrm{BCE}$ (Rosenswig et al., 2015). Between 1000 and $850 \mathrm{BCE}$, under still dry conditions, there is evidence for increased maize agriculture in the Pacific flood basin (Rosenswig et al., 2015) and within the Olmec area on the Gulf of Mexico coast (Arnold, 2009), and maize grains (AMS ${ }^{14} \mathrm{C}$ dated to $875 \pm 29 \mathrm{BCE}$ ) have been found as far as Ceibal within the CML (Inomata et al., 2015). We speculate that wetter conditions after $850 \mathrm{BCE}$ might have been unfavourable for further development of intensive agriculture in the CML. This is supported by palynological evidence, indicating that widespread land clearance and agriculture activity did not occur before $~ 400 \mathrm{BCE}$ (Wahl et al., 2007; Galop et al., 2004; Islebe et al., 1996; Leyden, 1987), despite some early local agricultural activity (Wahl et al., 2014; Rushton et al., 2013; McNeil et al., 2010). A return to drier conditions during the Late Pre-Classic period coincided with an expansion of maize-based agriculture in the CML, and communities within the Maya lowlands show strong and steady development (Hansen, 2017; Inomata and Henderson, 2016). Hence, major development of Maya civilisation in the central Maya lowlands occurred only after the onset of the Late Pre-Classic period, when climate became progressively drier, in line with earlier findings that drier conditions were favourable for agricultural development in the CML (Wahl et al., 2014). Changes in the distribution of rainfall probably also changed, and large floods, most evident during the Archaic and Early Pre-Classic period, occurred much less frequently after approximately $1000 \mathrm{BCE}$.

\section{Conclusions}

For the first time a regional palaeo-precipitation record has been reconstructed for the central Maya lowlands (CML), based on an exceptionally well-dated high-resolution beach ridge record. This record indicates centennial-scale precipitation fluctuations during the Pre-Classic period that are not always registered in local records, adding valuable new insights into larger-scale climatic forcing mechanisms for the CML. The generally poor correlation between the regional and local palaeo-precipitation reconstructions are probably related to spatial precipitation variability and chronological uncertainties of many records. Additional research of beach ridge formation processes are needed to extend this regional precipitation reconstruction to the Classic and Post-Classic period.

We have also generated a local-scale palaeo-precipitation record using diatoms preserved in a core from Lake Tuspan, thereby adding an alternative proxy to the relatively high number of local reconstructions predominantly based on oxygen isotope variability. We recognise, however, that diatom preservation is often poor in the carbonate lakes across the wider region. As a result, the correlation between these two reconstructions is variable through time.

Although the occurrence of a prolonged drought during the end of the Early Pre-Classic period, which we report here, is evident in other palaeo-precipitation reconstructions from the CML, the subsequent wet period during the Middle Pre-Classic period, registered in both our new records, is less evident elsewhere. Although many researchers have focused on the impact of drought on the development and disintegration of Maya societies, one should consider this prolonged wet period as potentially unfavourable for the development and intensification of agriculture in the CML, particularly in the wetter areas. We cannot be certain about the impact of wetter conditions on the Maya. However, owing to the lack of development at this time, we theorise that the wet period could have created poor growing conditions for maize in the CML. In order to test this theory, we advocate the use of process-based modelling approaches which capture heterogeneous environmental constraints on crop growth for given climate boundary conditions, such as the approach applied by Dermody et al. (2014).

Our results provide evidence that North Atlantic atmospheric-oceanic forcing plays an important role in the modulation of the observed centennial-scale precipitation variability; however, further studies are required which compare well-dated terrestrial reconstructions that capture regional signals with solar and oceanic reconstructions to gain 
a better understanding of climate forcing mechanisms, both in the CML and across the wider region.

Data availability. The relative beach ridge elevation record, spanning the Pre-Classic period, as well as the complete PC-1, amorphous silica, charred plant fragments and flood layer record of lake Tuspan core C (Fig. 4a), are available at the PANGAEA website (Nooren et al., 2018). 


\section{Appendix A}

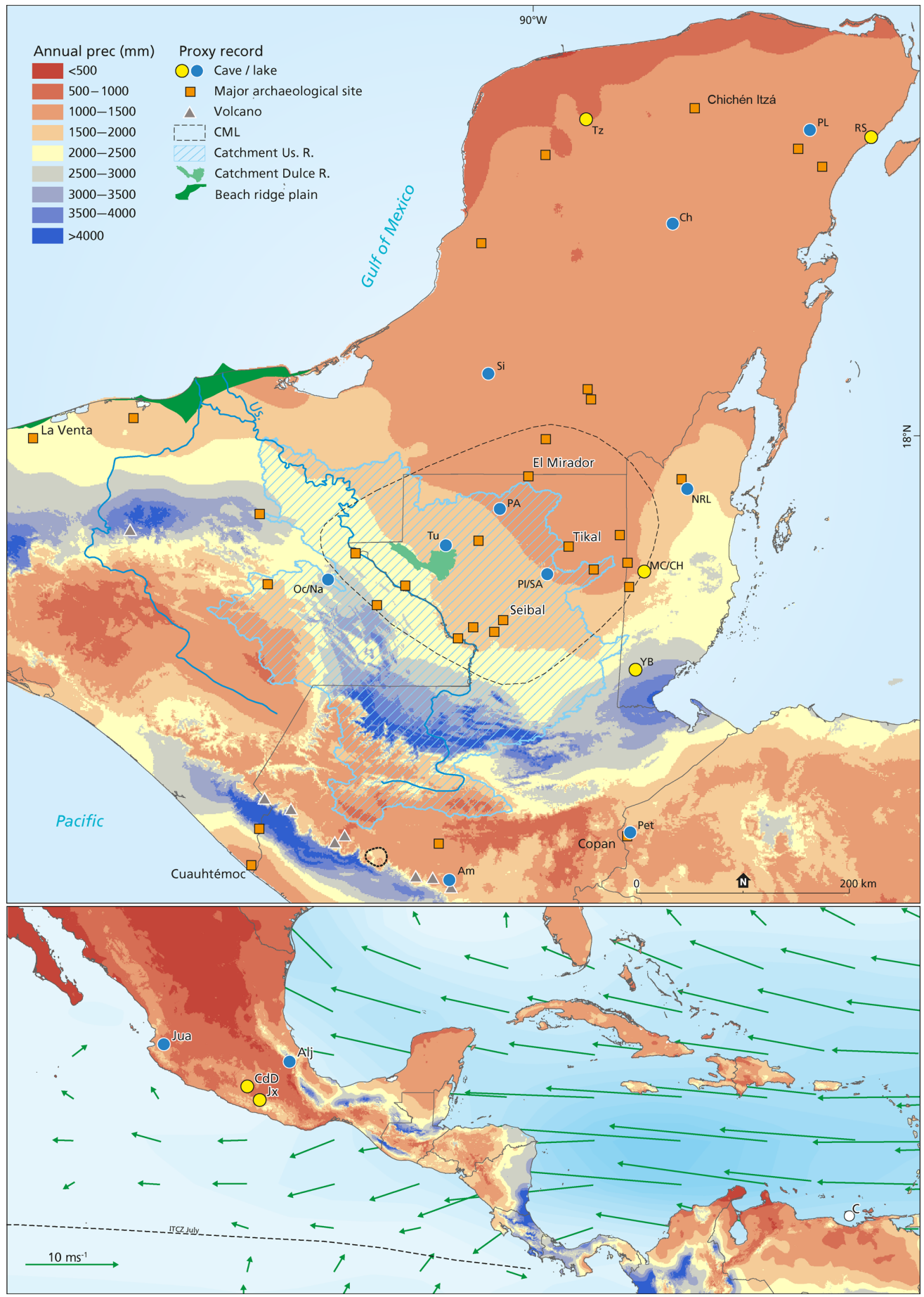

Figure A1. Location of proxy records indicated in Fig. A2 and/or mentioned in the main text. (a) Northern Maya lowlands (Tz: Tzabnah; PL: Punta Laguna; RS: Rio Secreto; Ch: Chichancanab; Si: Silvituc), the central and southern Maya lowlands (PA: Puerto Arturo; NRL: New River Lagoon; Tu: Tuspan; PI/Sa: Petén-Itzá and Salpeten; MC/CH: Macal Chasm and Chen Ha; YB: Yok Balum), the Maya highlands (Oc/Na: Ocotalito and Naja; Am: Amatitlan; Pet: Petapilla). (b) Central Mexico (Jua: Juanacatlán; CdD: Cueva del Diablo; Jx: Juxtlahuaca; Alj: Aljojuca) and the marine record from the Cariaco (C) basin. Annual precipitation (1950-2000) calculated with WorldClim version

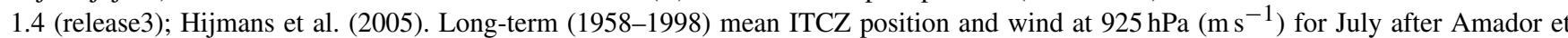
al. (2006), based on NCED/NCAR Reanalysis data (Kalnay et al., 1996). 

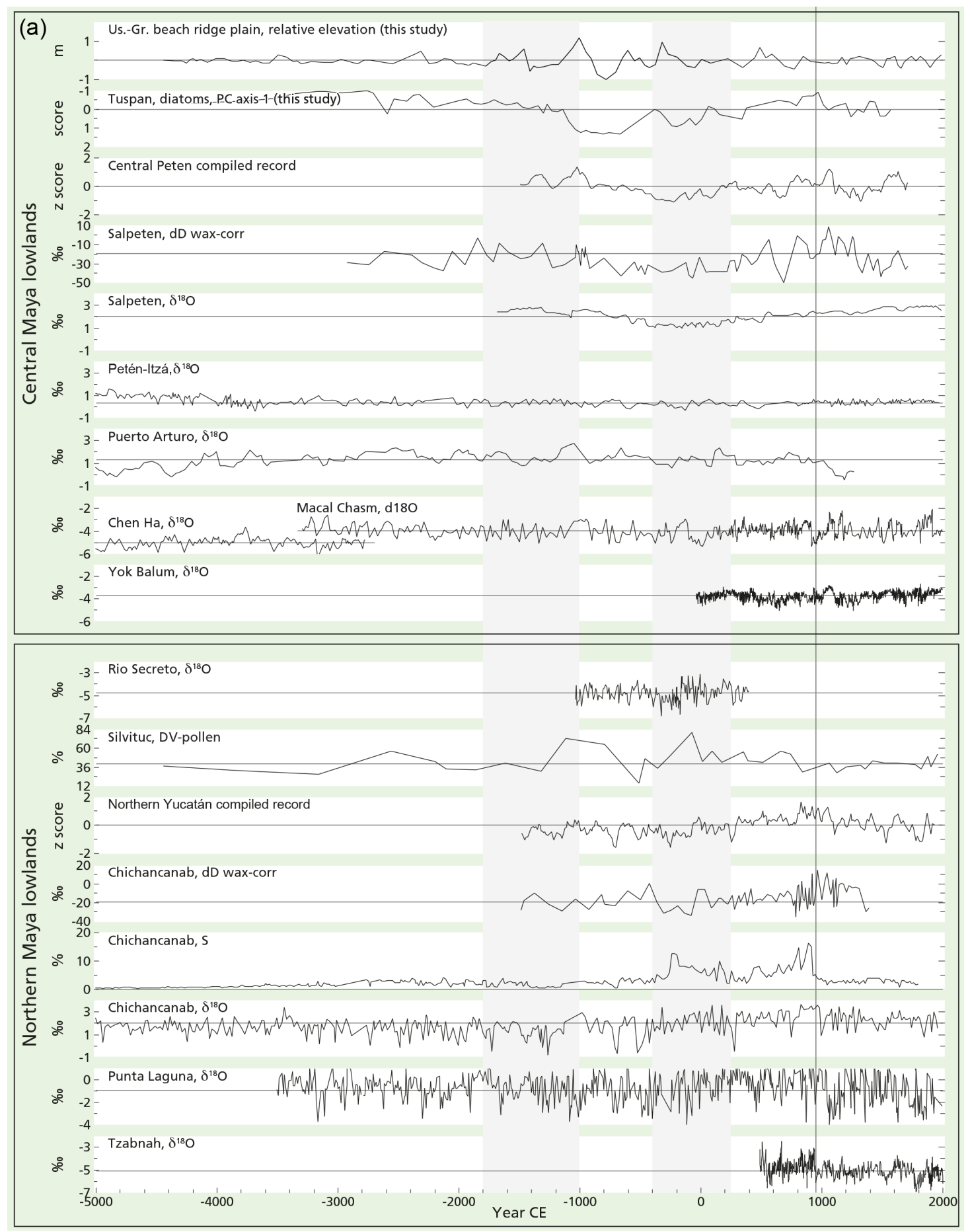

Figure A2. 

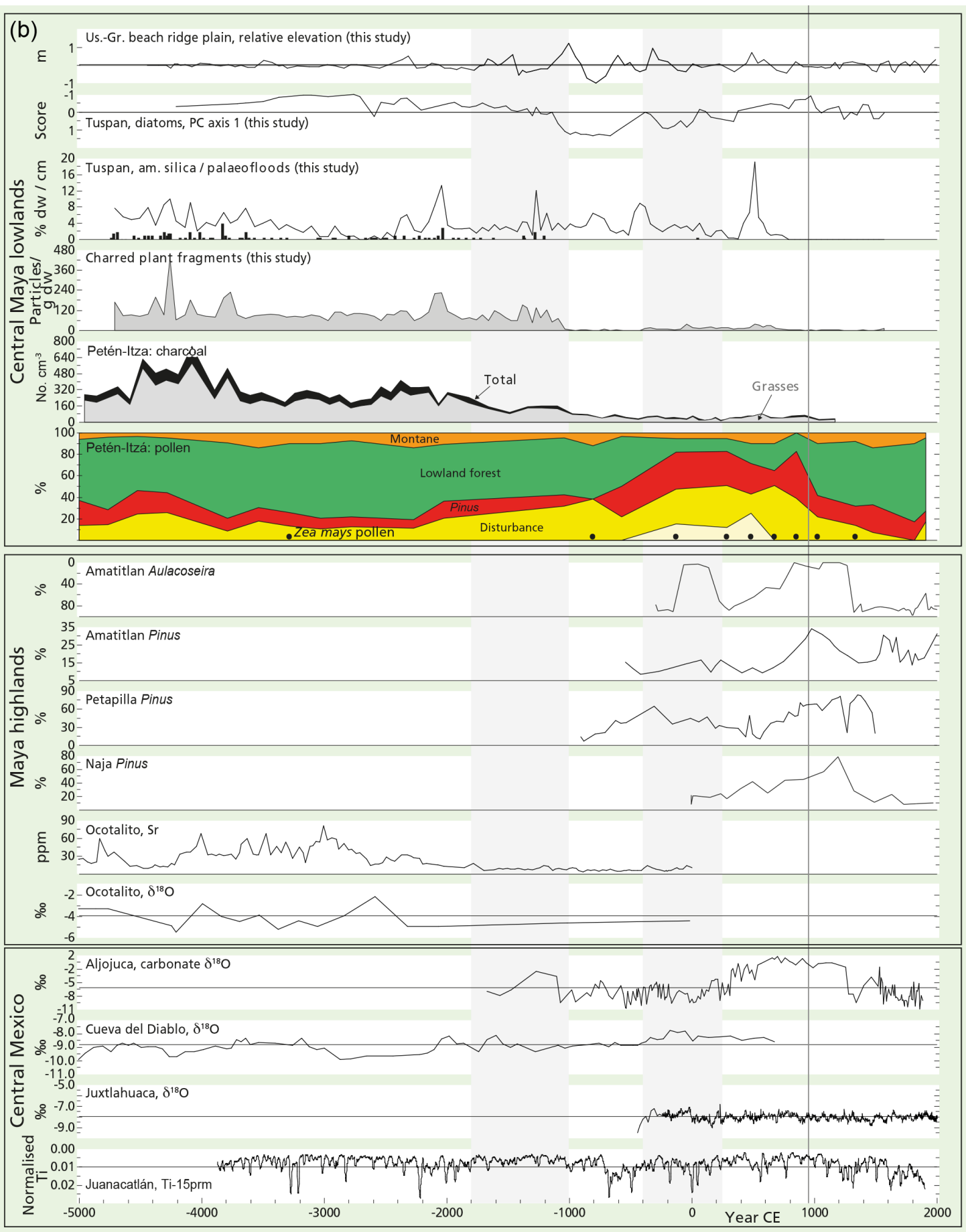

Figure A2. (a) Palaeo-precipitation records from the central Maya lowlands and Yucatán. Beach ridge elevation and Tuspan diatom record (this study), compiled record of Central Peten and Yucatán (Douglas et al., 2016), Salpeten and Chichancanab dD wax-corr. (Douglas et al., 2015), Salpeten $\delta^{18} \mathrm{O}$ (Rosenmeier et al., 2002), Petén-Itzá $\delta^{18} \mathrm{O}$ (Curtis et al., 1998), Puerto Arturo $\delta^{18} \mathrm{O}$ (Wahl et al., 2014), Macal Chasm $\delta^{18} \mathrm{O}$ (Akers et al., 2016), Chen Ha $\delta^{18} \mathrm{O}$ (Pollock et al., 2016), Yok Balum $\delta^{18} \mathrm{O}$ (Kennett et al., 2012), Rio Secreto $\delta^{18} \mathrm{O}$ (Medina-Elizalde et al., 2016), Silvituc disturbance vegetation (DV) pollen (Torrescano-Valle and Islebe, 2015), Chichancanab S and $\delta^{18} \mathrm{O}$ (Hodell et al., 1995), Punta Laguna $\delta^{18} \mathrm{O}$ (Hodell et al., 2007) and Tzabnah $\delta^{18} \mathrm{O}$ (Medina-Elizalde et al., 2010). Notice that the $y$ axis is sometimes reversed, so that excursions above the $x$ axis always indicate relatively drier conditions. (b) Proxy records from the central Maya lowlands, the Maya highlands and central Mexico. Petén-Itzá charcoal (Schüpbach et al., 2015), Petén-Itzá pollen (Islebe et al., 1996), Amatitlan Aulacoseira and Pinus (Velez et al., 2011), Petapilla Pinus (McNeil et al., 2010), Naja Pinus (Domínguez-Vázquez and Islebe, 2008), Ocotalito Sr (Díaz et al., 2017), Aljojuca $\delta^{18} \mathrm{O}$ (Bhattacharya et al., 2015), Cueva del Diablo $\delta^{18} \mathrm{O}$ (Bernal et al., 2011), Juxtlahuaca $\delta^{18} \mathrm{O}$ (Lachniet et al., 2013, 2017), and Juanacatlán Ti 15-point running mean (Jones et al., 2015). 


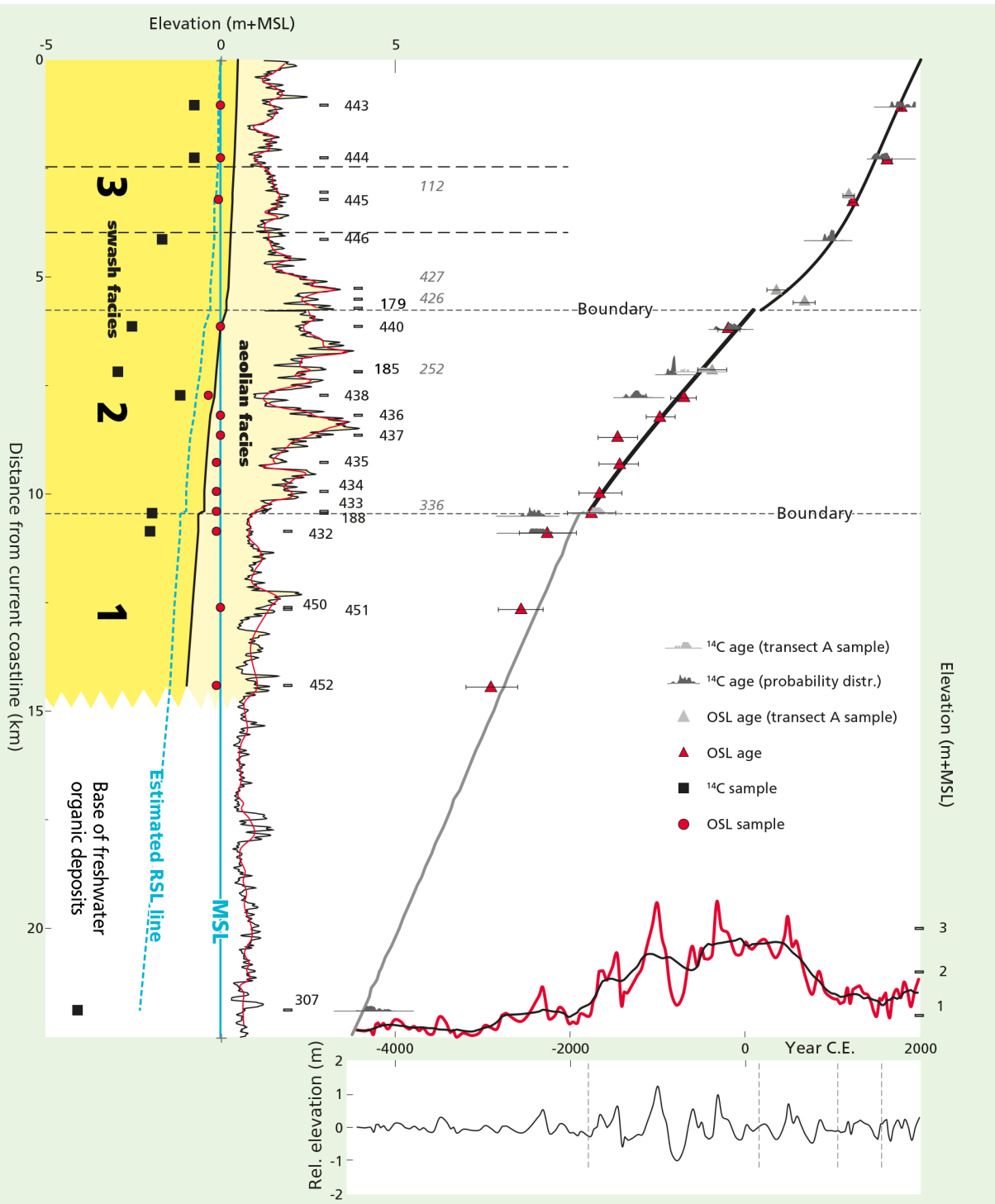

Figure A3. Age-distance model for beach ridge transect B. We refer to Nooren et al. (2017b) for further details. 


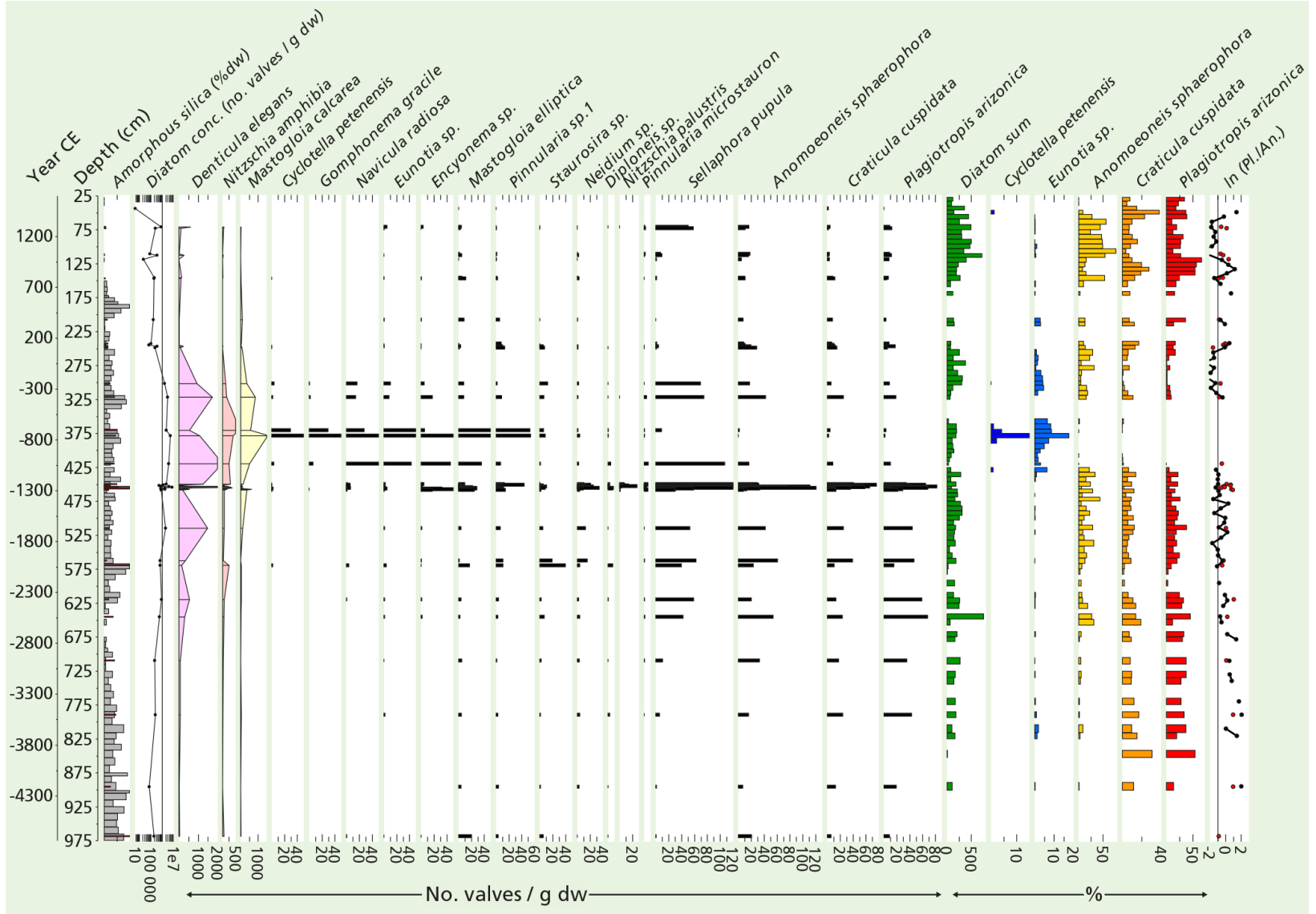

Figure A4. Diatom record for lake Tuspan core C. Diatom concentrations $\left(\times 1000\right.$ valves $\left.\mathrm{g}^{-1} \mathrm{dw}\right)$ were determined on $37 \mathrm{selected} 1 \mathrm{~cm}$ samples, and diatom percentages (only the "key species" are shown here) were determined on the 123 subsamples at $4-12 \mathrm{~cm}$ contiguous intervals. The small and often dominant Denticula elegans and Nitzschia amphibia species were excluded from the diatom sum.

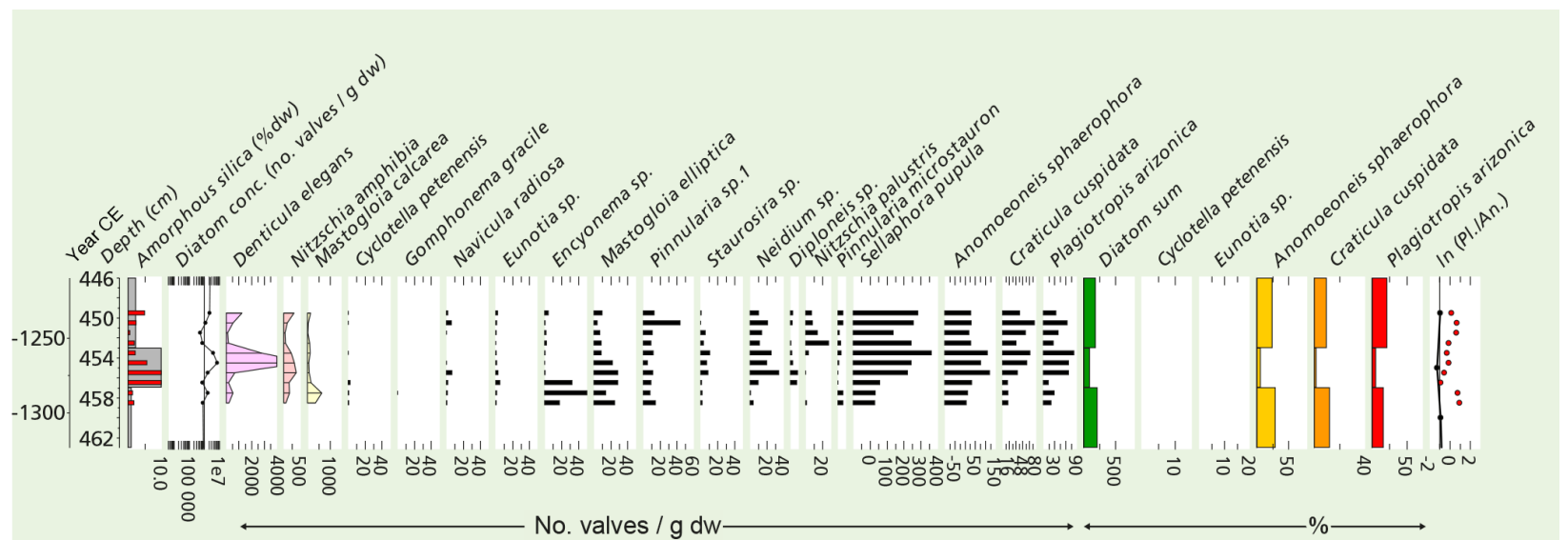

Figure A5. Detailed diatom record around one of the larger flood events 1200 BCE. 


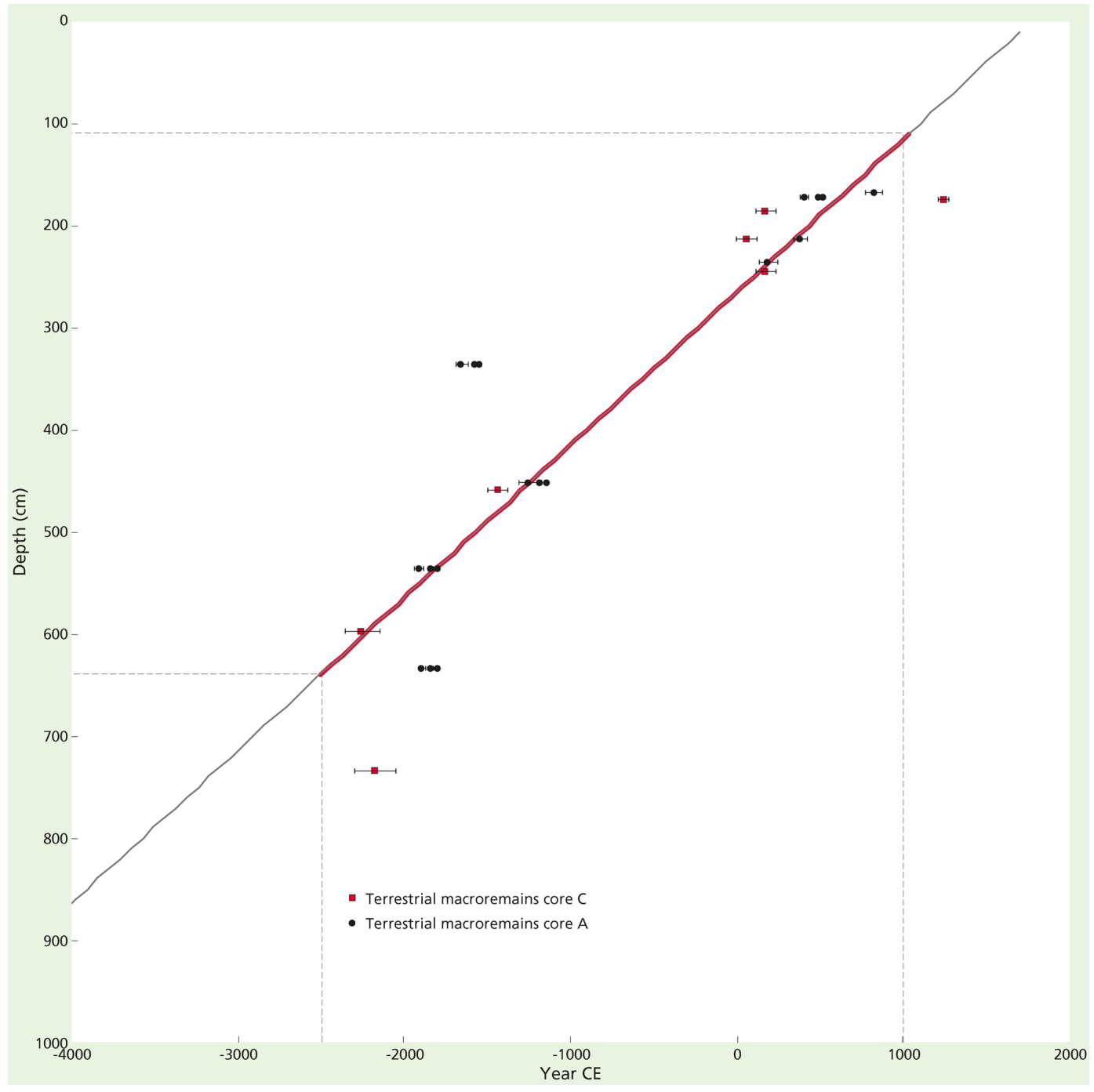

Figure A6. Age-depth model for Tuspan core C. The age-depth model is based on a linear interpolation between calibrated ages of radiocarbon-dated terrestrial macro-remains from core A (Galop et al., 2004) and core C (Fleury et al., 2014). The model is most reliable for ages between $~ 2500 \mathrm{BCE}$ and $1000 \mathrm{CE}$. 


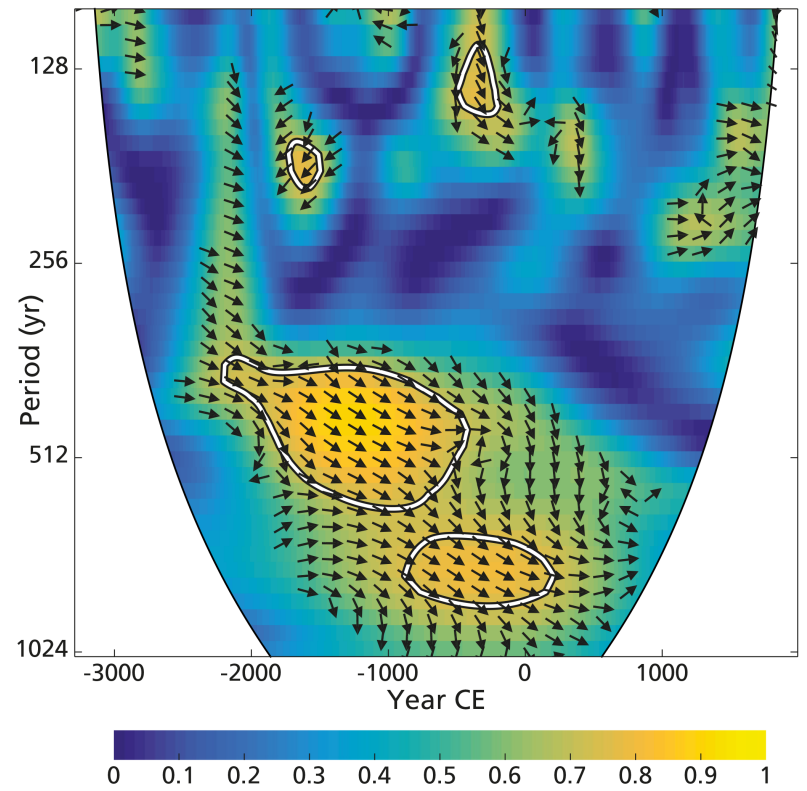

Figure A7. Wavelet transform coherence (WTC) analysis between the beach ridge record and the Macal Chasm $\delta^{18} \mathrm{O}$ record (Akers et al., 2016). The $5 \%$ significance level against red noise is shown as a thick contour. Arrows indicate phase difference, with an in-phase relationship between records if arrows point to the right.

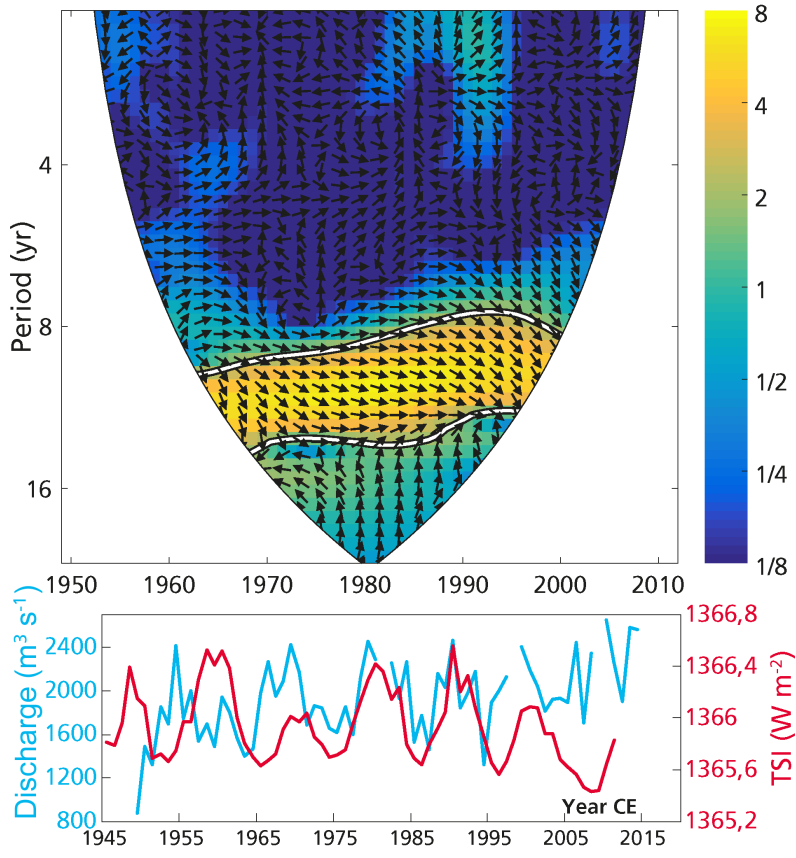

Figure A8. Mean annual discharge of the Usumacinta river at Boca del Cerro (Banco Nacional de Datos de Aguas Superficiales, 2017) compared with the total solar irradiance (TSI). The TSI is comprised of the reconstruction from 1700 to 2004 (Krivova et al., 2007), concatenated with observations from the Total Irradiance Monitor (TIM) on NASA's Solar Radiation and Climate Experiment (SORCE) from 2005 to 2011 (Kopp and Lean, 2011). In total, $4.56 \mathrm{~W}$ is added to the TIM measurements as previous reconstructions were calibrated against less accurate measuring equipment, compared with the TIM instrument, which led to an overestimation of TSI. 


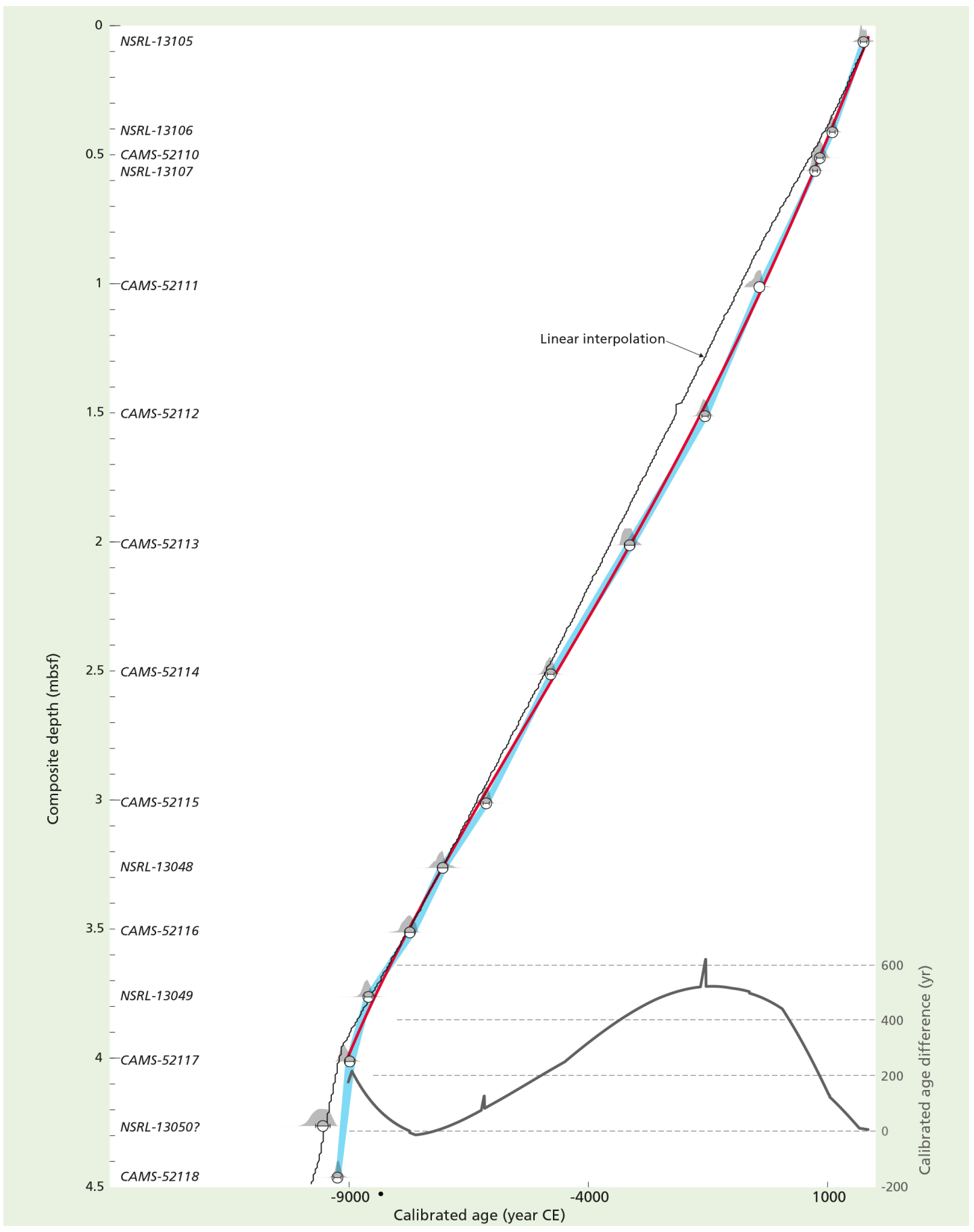

Figure A9. Updated age-depth model for Cariaco core 1002D. Original model (Haug et al., 2001) has been based on a linear interpolation of calibrated ages. We applied a fourth-order polynomial fit through modelled ages calculated with a P_sequence model (Oxcal 4.2) (Bronk Ramsey, 2009, 2016): $k=10$; Marine13 calibration curve; Delta $R=15 \pm 50$; one outlier: NSRL-13050. 
Competing interests. The authors declare that they have no conflict of interest.

Acknowledgements. This research is supported by the Netherlands Organization for Scientific Research (NWO-grant 821.01.007). The lidar data were generously provided by INEGI, Mexico. We acknowledge Philippe Martinez, Jacques Giraudeau and Pierre Carbonel for the XRF core scan measurements, and we would like to thank Peter Douglas, Pete Akers and Gerald Haug for providing their data. We thank Konrad Hughen for valuable suggestions for updating the age-depth model for Cariaco's sediment core $1002 \mathrm{D}$. We thank Ton Markus for improving the figures and Mark Brenner and an anonymous reviewer for their valuable comments for improving the paper.

Edited by: Alessio Rovere

Reviewed by: Mark Brenner and one anonymous referee

\section{References}

Akers, P. D., Brook, G. A., Railsback, L. B., Liang, F., Iannone, G., Webster, J. W., Reeder, P. P., Cheng, H., and Edwards, R. L.: An extended and higher-resolution record of climate and land use from stalagmite MC01 from Macal Chasm, Belize, revealing connections between major dry events, overall climate variability, and Maya sociopolitical changes, Palaeogeogr. Palaeocl., 459, 268-288, 2016.

Amador, J. A., Alfaro, E. J., Lizano, O. G., and Magaña, V. O.: Atmospheric forcing of the eastern tropical Pacific: A review, Prog. Oceanogr., 69, 101-142, 2006.

Anselmetti, F. S., Hodell, D. A., Ariztegui, D., Brenner, M., and Rosenmeier, M. F.: Quantification of soil erosion rates related to ancient Maya deforestation, Geology, 35, 915-918, 2007.

Arnold III, P. J.: Settlement and subsistence among the Early Formative Gulf Olmec, J. Anthropol. Archaeol., 28, 397-411, 2009.

Banco Nacional de Datos de Aguas Superficiales, Conagua: http://www.conagua.gob.mx/CONAGUA07/Contenido/Document os/Portada BANDAS.htm, last access: January 2017.

Batterbee, R. W.: A new method for estimating absolute microfossil numbers with special reference to diatoms, Limnol. Oceonogr., 18, 647-653, 1973.

Beach, T., Luzzadder-Beach, S., Cook, D., Dunning, N., Kennett, D. J., Krause, S., Terry, R., Trein, D., and Valdez, F.: Ancient Maya impacts on the Earth's surface: An Early Anthropocene analog?, Quaternary Sci. Rev., 124, 1-30, 2015.

Bernal, J. P., Lachniet, M., McCulloch, M., Mortimer, G., Morales, P., and Cienfuegos, E.: A speleothem record of Holocene climate variability from southwestern Mexico, Quaternary Res., 75, 104113, 2011

Bhattacharya, T., Byrne, R., Böhnel, H., Wogau, K., Kienel, U., Ingram, B. L., and Zimmerman, S.: Cultural implications of late Holocene climate change in the Cuenca Oriental, Mexico, P. Natl. Acad. Sci. USA, 112, 1693-1698, 2015.

Bond, G., Kromer, B., Beer, J., Muscheler, R., Evans, M. N., Showers, W., Hoffmann, S., Lotti-Bond, R., Hajdas, I., and Bonani, G.: Persistent Solar Influence on North Atlantic Climate During the Holocene, Science, 294, 2130-2136, 2001.
Bronk Ramsey, C.: Bayesian analysis of radiocarbon dates, Radiocarbon, 51, 337-360, 2009.

Bronk Ramsey, C.: Oxcal 4. 2., available at: http://c14.arch.ox.ac. uk/oxcal.html (last access: January 2017), 2016.

Burney, D. A. and Pigott Burney, L.: Holocene Charcoal Stratigraphy from Laguna Tortuguero, Puerto Rico, and the Timing of Human Arrival on the Island, J. Archaeol. Sci., 21, 273-281, 1994.

Coe, M. D.: The Maya, 8th edn., Thames and Hudson, London, UK, 2011.

Curtis, J. H., Brenner, M., Hodell, D. A., Balser, R. A., Islebe, G. A., and Hooghiemstra, H.: A multiproxy study of Holocene environmental change in the Maya Lowlands of Peten, Guatemala, J. Paleolimnol., 19, 139-159, 1998.

Czarnecki, D. B. and Blinn, D. W.: Observations on Southwestern Diatoms. I. Plagiotropis arizonica N. Sp. (Bacillariophyta, Entomoneidaceae), a large Mesohalobous Diatom, T. Am. Microsc. Soc., 97, 393-396, 1978.

Davies, S. J., Lamb, H. F., and Roberts, S. J.: Micro-XRF Core Scanning in Palaeolimnology: Recent Developments, in: MicroXRF Studies of Sediment Cores, edited by: Croudace, I. W. and Rothwell, R. G., Springer, Dordrecht, the Netherlands, 189-226, 2015.

Dermody, B. J., van Beek, R. P. H., Meeks, E., Klein Goldewijk, K., Scheidel, W., van der Velde, Y., Bierkens, M. F. P. Wassen, M. J., and Dekker, S. C.: A virtual water network of the Roman world, Hydrol. Earth Syst. Sci., 18, 5025-5040, https://doi.org/10.5194/hess-18-5025-2014, 2014.

Díaz, K. A., Pérez, L., Correa-Metrio, A., Franco-Gaviria, J. F., Echeverria, P., Curtis, J., and Brenner, M.: Holocene environmental history of tropical, mid-altitude Lake Ocotalito, México, inferred from ostracodes and non-biological indicators, Holocene, 27, 1308-1317, 2017.

Domínguez-Vázquez, G. and Islebe, G. A.: Protracted drought during the late Holocene in the Lacandon rain forest, Mexico, Veg. Hist. Archaeobot., 17, 327-333, 2008.

Douglas, P. M. J., Pagani, M., Canuto, M. A., Brenner, M., Hodell, D. A., Eglinton, T. I., and Curtis, J. H.: Drought, agricultural adaptation, and sociopolitical collapse in the Maya Lowlands, P. Natl. Acad. Sci. USA, 112, 5607-5612, 2015.

Douglas, P. M. J., Demarest, A. A., Brenner, M., and Canuto, M. A.: Impacts of Climate Change on the Collapse of Lowland Maya Civilization, Annu. Rev. Earth Pl. Sc., 44, 613-645, 2016.

Dunning, N. P., Beach, T. P., and Luzzadder-Beach, S.: Kax and kol: Collapse and resilience in lowland Maya civilization, P. Natl. Acad. Sci. USA, 109, 3652-3657, 2012.

Dunning, N. P., McCane, C., Swinney, T., Purtill, M., Sparks, J., Mann, A., McCool, J.-P., and Ivenso, C.: Geoarchaeological Investigations in Mesoamerica Move into the 21st Century: A Review, Geoarchaeology, 30, 167-199, 2015.

Ebert, C. E., Peniche May, N., Culleton, B. J., Awe, J. J., and Kennett, D. J.: Regional response to drought during the formation and decline of PreClassic Maya societies, Quaternary Sci. Rev., 173, 211-235, 2017.

Fleury, S., Malaizé, B., Giraudeau, J., Galop, D., BoutRoumazeilles, V., Martinez, P., Charlier, K., Carbonel, P., and Arnauld, M.-C.: Impacts of Mayan land use on Laguna Tuspan watershed (Petén, Guatemala) as seen through clay and ostracode analysis, J. Archaeol. Sci., 49, 372-382, 2014. 
Ford, A. and Nigh, R.: The Maya Forest Garden: Eight Millennia of Sustainable Cultivation of the Tropical Woodland, Taylor and Francis, London, New York, USA, 2015.

Galop, D., Lemonnier, E., Carozza, J. M., and Metailie, J. P.: Bosques, milpas, casas y aguadas de antaño, in: La Joyanca, ciudad maya del noroeste del Peten (Guatemala), edited by: Arnauld, C. and Breuil-Martinez, V., CEMCA, CIRMA, Associacion Tikal, Guatemala, 55-71, 2004.

Gasse, F., Juggins, S., and Ben Khelifa, L.: Diatom-based transfer functions for inferring past hydrochemical characteristics of African lakes, Palaeogeogr. Palaeocl., 117, 31-54, 1995.

Grinsted, A., Moore, J. C., and Jevrejeva, S.: Application of the cross wavelet transform and wavelet coherence to geophysical time series, Nonlin. Processes Geophys., 11, 561-566, https://doi.org/10.5194/npg-11-561-2004, 2004.

Hansen, R. D.: The Feast Before Famine and Fighting: The Origins and Consequences of Social Complexity in the Mirador Basin, Guatemala. Feast, Famine or Fighting? Multiple Pathways to Social Complexity, edited by: Chacon, R. J. and Mendoza, R. G., Springer, Dordrecht, the Netherlands, 305-335, 2017.

Haug, G. H., Hughen, K. A., Sigman, D. M., Peterson, L. C., and Röhl, U.: Southward Migration of the Intertropical Convergence Zone Through the Holocene, Science, 293, 1304-1308, 2001.

Haug, G. H., Gunther, D., Peterson, L. C., Sigman, D. M., Hughen, K. A., and Aeschlimann, B.: Climate and the Collapse of Maya Civilization, Science, 299, 1731-1735, 2003.

Hijmans, R. J., Cameron, S. E., Parra, J. L., Jones, P. G., and Jarvis, A.: Very high resolution interpolated climate surfaces for global land areas, Int. J. Climatol., 25, 1965-1978, 2005.

Hodell, D. A., Curtis, J. H., and Brenner, M.: Possible role of climate in the collapse of Classic Maya civilization, Nature, 375, 391-394, 1995.

Hodell, D. A., Brenner, M., Curtis, J. H., and Guilderson, T.: Solar forcing of drought frequency in the Maya lowlands, Science, 292, 1367-1369, 2001.

Hodell, D. A., Brenner, M., and Curtis, J. H.: Terminal Classic drought in the northern Maya lowlands inferred from multiple sediment cores in Lake Chichancanab (Mexico), Quaternary Sci. Rev., 24, 1413-1427, 2005.

Hodell, D. A., Brenner, M., and Curtis, J. H.: Climate and cultural history of the Northeastern Yucatan Peninsula, Quintana Roo, Mexico, Climatic Change, 83, 215-240, 2007.

Hoggarth, J. A., Breitenbach, S. F. M., Culleton, B. J., Ebert, C. E., Mason, M. A., and Kennett, D. J.: The political collapse of Chichén Itzá in climatic and cultural context, Global Planet. Change, 138, 25-42, 2016.

Iannone, G.: The Great Maya Droughts in Cultural Context: Case Studies in Resilience and Vulnerability, Univ Press of Colorado, Boulder, CO, USA, 2014.

Inomata, T. and Henderson, L.: Time tested: re-thinking chronology and sculptural traditions in Preclassic southern Mesoamerica, Antiquity, 90, 456-471, 2016.

Inomata, T., MacLellan, J., Triadan, D., Munson, J., Burham, M., Aoyama, K., Nasu, H., Pinzón, F., and Yonenobu, H.: Development of sedentary communities in the Maya lowlands: Coexisting mobile groups and public ceremonies at Ceibal, Guatemala, P. Natl. Acad. Sci. USA, 112, 4268-4273, 2015.
Islebe, G. A., Hooghiemstra, H., Brenner, M., Curtis, J. H., and Hodell, D. A.: A Holocene vegetation history from lowland Guatemala, Holocene, 6, 265-271, 1996.

Jones, M. D., Metcalfe, S. E., Davies, S. J., and Noren, A.: Late Holocene climate reorganisation and the North American Monsoon, Quaternary Sci. Rev., 124, 290-295, 2015.

Kalnay E., Kanamitsu, M., Kistler, R., Collins, W., Deaven, D., Gandin, L., Iredell, M., Saha, S., White, G., Woollen, J., Zhu, Y., Chelliah, M., Ebisuzaki, W., Higgins, W., Janowiak, J., Mo, K. C., Ropelewski, C., Wang, J., Leetmaa, A., Reynolds, R., Jenne, R., and Joseph, D.: The NCEP/NCAR Reanalysis 40-year Project, B. Am. Meteorol. Soc., 77, 437-471, 1996.

Kennett, D. J., Breitenbach, S. F. M., Aquino, V. V., Asmerom, Y., Awe, J., Baldini, J. U. L., Bartlein, P., Culleton, B. J., Ebert, C., Jazwa, C., Macri, M. J., Marwan, N., Polyak, V., Prufer, K. M., Ridley, H. E., Sodemann, H., Winterhalder, B., and Haug, G. H.: Development and disintegration of Maya political systems in response to climate change, Science, 338, 788-791, 2012.

Kopp, G. and Lean, J. L.: A new, lower value of total solar irradiance: Evidence and climate significance, Geophys. Res. Lett., 38, L01706, https://doi.org/10.1029/2010GL045777, 2011.

Krivova, N. A., Balmaceda, L., and Solanki, S. K.: Reconstruction of solar total irradiance since 1700 from the surface magnetic flux, Astron. Astrophys., 467, 335-346, 2007.

Lachniet, M. S., Asmerom, Y., Bernal, J. P., Polyak, V., and Vazquez-Selem, L.: Orbital pacing and ocean circulationinduced collapses of the Mesoamerican monsoon over the past 22000 y, P. Natl. Acad. Sci. USA, 110, 9255-9260, 2013.

Lachniet, M. S., Asmerom, Y., Polyak, V., and Bernal, J. P.: Two millennia of Mesoamerican monsoon variability driven by $\mathrm{Pa}-$ cific and Atlantic synergistic forcing, Quaternary Sci. Rev., 155, 100-113, 2017.

Lee, S., Gaiser, E., VanDeVijver, B., Edlund, M. B., and Spaulding, S. A.: Morphology and typification of Mastogloia smithii and M. lacustris, with descriptions of two new species form the Florida Everglades and the Caribbean region, Diatom Res., 29, 325-350, 2014.

Lentz, D. L., Dunning, N. P., Scarborough, V. L., Magee, K. S., Thompson, K. M., Weaver, E., Carr, C., Terry, R. E., Islebe, G., Tankersley, K. B., Grazioso Sierra, L., Jones, J. G., Buttles, P., Valdez, F., and Ramos Hernandez, C. E.: Forests, fields, and the edge of sustainability at the ancient Maya city of Tikal, P. Natl. Acad. Sci. USA, 111, 18513-18518, 2014.

Leyden. B. W.: Man and Climate in the Maya Lowlands, Quaternary Res., 28, 407-414, 1987.

Lohse, J.: Archaic Origins of the Lowland Maya, Lat. Am. Antiq., 21, 312-352, 2010.

McNeil, C. L., Burney, D. A., and Burney, L. P.: Evidence disputing deforestation as the cause for the collapse of the ancient Maya polity of Copan, Honduras, P. Natl. Acad. Sci. USA, 107, 1017$1022,2010$.

Medina-Elizalde, M., Burns, S. J., Lea, D. W., Asmerom, Y., von Gunten, L., Polyak, V., Vuille, M., and Karmalkar, A.: High resolution stalagmite climate record from the Yucatan Peninsula spanning the Maya terminal classic period, Earth Planet. Sc. Lett., 298, 255-262, 2010.

Medina-Elizalde, M., Burns, S. J., Polanco-Martinez, J. M., Beach, T., Lases-Hernandez, F., Shen, C. C., and Wang, H. C.: Highresolution speleothem record of precipitation from the Yucatan 
Peninsula spanning the Maya Preclassic Period, Global Planet. Change, 138, 93-102, 2016.

Metcalfe, S., Breen, A., Murray, M., Furley, P., Fallick, A., and McKenzie, A.: Environmental change in northern Belize since the latest Pleistocene, J. Quaternary Sci., 24, 627-641, 2009.

Metcalfe, S. E., Barron, J. A., and Davies, S. J.: The Holocene history of the North American Monsoon: 'known knowns' and 'known unknowns' in understanding its spatial and temporal complexity, Quaternary Sci. Rev., 120, 1-27, 2015.

Mueller, A. D., Islebe, G. A., Hillesheim, M. B., Grzesik, D. A., Anselmetti, F. S., Ariztegui, D., Brenner, M., Curtis, J. H., Hodell, D. A., and Venz, K. A.: Climate drying and associated forest decline in the lowlands of northern Guatemala during the Holocene, Quaternary Res., 71, 133-141, 2009.

Nooren, K., Hoek, W. Z., Van der Plicht, H., Sigl, M., Van Bergen, M. J., Galop, D., Torrescano-Valle, N., Islebe, G., Huizinga, A., Winkels, T., and Middelkoop, H.: Explosive eruption of El Chichón volcano (Mexico) disrupted 6th century Maya civilization and contributed to global cooling, Geology, 45, 175-178, $2017 \mathrm{a}$.

Nooren, K., Hoek, W. Z., Winkels, T., Huizinga, A., Van der Plicht, H., Van Dam, R. L., Van Heteren, S., Van Bergen, M. J., Prins, M. A., Reimann, T., Wallinga, J., Cohen, K. M., Minderhoud, P., and Middelkoop, H.: The Usumacinta-Grijalva beach-ridge plain in southern Mexico: a high-resolution archive of river discharge and precipitation, Earth Surf. Dynam., 5, 529-556, https://doi.org/10.5194/esurf-5-529-2017, 2017b.

Nooren, K., Hoek, W. Z., Dermody, B. J., Galop, D., Metcalfe, S., Islebe, G., and Middelkoop, H.: Two palaeoprecipitation records for the Central Maya Lowlands, spanning the Pre-Classic period (1800 BCE-250 CE), PANGAEA, https://doi.org/10.1594/PANGAEA.892800, 2018.

Novelo, E., Tavera, R., and Ibarra, C.: Bacillariophyceae from karstic wetlands in Mexico, J. Cramer, Berlin, Germany, 2007.

Paillès, C., Sylvestre, F., Escobar, J., Tonetto, A., Rustig, S., and Mazur, J.-C.: Cyclotella petenensis and Cyclotella cassandrae, two new fossil diatoms from Pleistocene sediments of Lake Petén-Itzá, Guatemala, Central America, Phytotaxa, 351, 247263, 2018

Patrick, R. and Reimer, C. W.: Diatoms of the United States, vol. I, Monograph 13, Acad. Nat. Sci., Philadelphia, USA, 1966.

Patrick, R. and Reimer, C. W.: Diatoms of the United States, vol. II, Part 1, Monograph 13, Acad. Nat. Sci., Philadelphia, USA, 1975.

Pollock, A. L., Van Beynen, P. E., De Long, K. L., Polyak, V., Asmerom, Y., and Reeder, P. P.: A mid-Holocene paleoprecipitation record from Belize, Palaeogeogr. Palaeocl., 463, 103-111, 2016.

Reed, J. M.: A diatom-conductivity transfer function for Spanish salt lakes, J. Paleolimnol., 19, 399-416, 1998.

Reimer, P. J., Bard, E., Bayliss, A., Warren Beck, J., Blackwell, P. G., Ramsey, C. B., Buck, C. E., Cheng, H., Lawrence Edwards, R., Friedrich, M., Grootes, P. M., Guilderson, T. P., Haflidason, H., Hajdas, I., Hatté, C., Heaton, T. J., Hoffmann, D. L., Hogg, A. G., Hughen, K. A., Felix Kaiser, K., Kromer, B., Manning, S. W., Niu, M., Reimer, R. W., Richards, D. A., Marian Scott, E., Southon, J. R., Staff, R. A, Turney, C. S. M., and Van der Plicht, $\mathrm{J}$. : IntCal13 and Marine13 radiocarbon age calibration curves 0 50,000 years cal BP, Radiocarbon, 55, 1869-1887, 2013.

Rosenmeier, M. F., Hodell, D. A., Brenner, M., Curtis, J. H., and Guilderson, T. P.: A 4000-year lacustrine record of environmen- tal change in the southern Maya lowlands, Peten, Guatemala, Quaternary Res., 57, 183-190, 2002.

Rosenswig, R. M., VanDerWarker, A. M., Culleton, B. J., and Kennett, D. J.: Is it agriculture yet? Intensified maize-use at $1000 \mathrm{cal}$ BC. in the Soconusco and Mesoamerica, J. Anthropol. Archaeol., 40, 89-108, 2015.

Rushton, E. A. C., Metcalfe, S. E., and Whitney, B. S. W.: A lateHolocene vegetation history from the Maya Lowlands, Lamanai, Northern Belize, Holocene, 23, 485-493, 2013.

Schneider, T., Bischoff, T., and Haug, G. H.: Migrations and dynamics of the intertropical convergence zone, Nature, 513, 4553,2014

Schüpbach, S., Kirchgeorg, T., Colombaroli, D., Beffa, G., Radaelli, M., Kehrwald, N. M., and Barbante, C.: Combining charcoal sediment and molecular markers to infer a Holocene fire history in the Maya Lowlands of Petén, Guatemala, Quaternary Sci. Rev., 115, 123-131, 2015.

Steinhilber, F. Abreu, J. A., Beer, J., Brunner, I., Christl, M., Fischer, H., Heikkilä, U., Kubik, P. W., Mann, M., McCracken, K. G., Miller, H., Miyahara, H., Oerter, H., and Wilhelms, F. 9,400 years of cosmic radiation and solar activity from ice cores and tree rings, P. Natl. Acad. Sci. USA, 109, 5967-5971, 2012.

Stuiver, M. and Braziunas, T. F.: Sun, ocean, climate and atmospheric ${ }^{14} \mathrm{CO}_{2}$ : an evaluation of causal and spectral relationships, Holocene, 3, 289-305, 1993.

Tankersley, K. B., Dunning, N. P., Scarborough, V., Huff, W. D., Lentz, D. L., and Carr, C.: Catastrophic volcanism and its implication for agriculture in the Maya Lowlands, J. Archaeol. Sci., 5, 465-470, 2016.

Thompson, J. E. S.: A Commentary on the Dresden Codex, Am Philosophical Society, Philadelphia, USA, 1972.

Torrescano-Valle, N. and Islebe, G. A.: Holocene paleoecology, climate history and human influence in the southwestern Yucatan Peninsula, Rev. Palaeobot. Palyno., 217, 1-8, 2015.

Turner II, B. L. and Sabloff, J. A.: Classic Period collapse of the Central Maya Lowlands: Insights about human-environment relationships for sustainability, P. Natl. Acad. Sci. USA, 109, 13908-13914, 2012.

USGS: Shuttle Radar Topography Mission (SRTM) 1 Arc-Second Global dataset, available at: https://lta.cr.usgs.gov/SRTM1Arc (last access: January 2017), 2009.

Valásquez Garciá, E.: The Maya Flood Myth and the Decapitation of the Cosmic Caiman, The PARI Journal, 7, 1-10, 2006.

Van Geel, B., Buurman, J., and Waterbolk, H. T.: Archaeological and palaeoecological indications for an abrupt climate change in The Netherlands and evidence for climatological teleconnections around 2650 BP, J. Quaternary Sci., 11, 451-460, 1996.

Velez, M. I., Curtis, J. H., Brenner, M., Escobar, J., Leyden, B. W., and Popenoe de Hatch, M.: Environmental and Cultural Changes in Highland Guatemala Inferred from Lake Amatitlán Sediments, Geoarchaeology, 26, 1-19, 2011.

Wahl, D., Byrne, R., Schreiner, T., and Hansen, R.: Palaeolimnological evidence of late-Holocene settlement and abandonment in the Mirador Basin, Peten, Guatemala, Holocene, 17, 813-820, 2007.

Wahl, D., Byrne, R., and Anderson, L.: An 8700 year paleoclimate reconstruction from the southern Maya lowlands, Quaternary Sci. Rev., 103, 19-25, 2014. 